\title{
Potential applications of personality assessments to the management of non-human primates: A review of 10 years of study
}

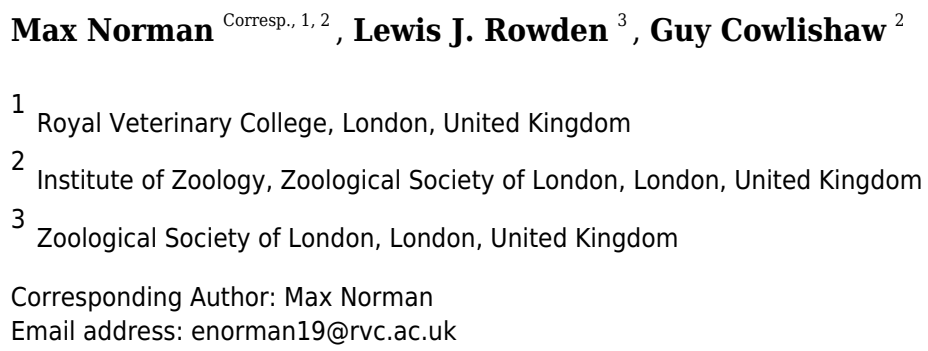

Studies of primate personality have become increasingly common over the past three decades. Recently, studies have begun to focus on the health, welfare and conservation implications of personality, and the potential applications of incorporating quantitative personality assessments into animal management programmes. However, this literature is dispersed across a multitude of settings and scientific disciplines. We conducted a review of nonhuman primate personality studies relevant to these issues published since 2010, following on from an earlier review. The databases ScienceDirect, PubMed and Web of Science were used to identify relevant articles. After eliminating irrelevant or duplicate papers, 69 studies were selected. Our review reveals that, while primate personality research is carried out on a range of species, there is strong taxonomic bias. While 28 species appeared within the reviewed literature, $52 \%$ of studies were carried out on just five species. Further, the most common research focus (42\%) was validating new assessment methods or describing personality in different species, rather than exploring the links between personality and animal welfare using existing validated methods. However, among the remaining studies that did explore the role of animal personality in husbandry, health, and welfare, we identified progression towards integrating personality data into various aspects of animal management. Evidence suggests the assessment of personality may benefit social group management, enrichment practices, training protocols, health and welfare monitoring, and conservation planning for endangered species. We argue that further research which develops our understanding of primate personality and its influence in these areas will provide a valuable tool to inform animal management practices. 
1 Potential Applications of Personality Assessments to the

2 Management of Nonhuman Primates: A Review of 10

3 Years of Study

4

5 Max Norman ${ }^{1,2}$, Lewis J. Rowden ${ }^{3}$, Guy Cowlishaw ${ }^{2}$,

$7 \quad{ }^{1}$ Royal Veterinary College, 4 Royal College St, London NW1 OTU, United Kingdom

$8{ }^{2}$ Institute of Zoology, Zoological Society of London, Regent's Park, London NW1 4RY,

9 United Kingdom

$10{ }^{3}$ Zoological Society of London, Regent's Park, London NW1 4RY, United Kingdom

12 Corresponding Author:

13 Max Norman

14 Summerseat, Church Road, West Hanningfield, Essex CM2 8UQ, United Kingdom

15 Email address: max.norman@invigoration.co.uk 


\section{Abstract}

18

Studies of primate personality have become increasingly common over the past three decades. Recently, studies have begun to focus on the health, welfare and conservation implications of personality, and the potential applications of incorporating quantitative personality assessments into animal management programmes. However, this literature is dispersed across a multitude of settings and scientific disciplines. We conducted a review of nonhuman primate personality studies relevant to these issues published since 2010, following on from an earlier review. The databases ScienceDirect, PubMed and Web of Science were used to identify relevant articles. After eliminating irrelevant or duplicate papers, 69 studies were selected. Our review reveals that, while primate personality research is carried out on a range of species, there is strong taxonomic bias. While 28 species appeared within the reviewed literature, $52 \%$ of studies were carried out on just five species. Further, the most common research focus $(42 \%)$ was validating new assessment methods or describing personality in different species, rather than exploring the links between personality and animal welfare using existing validated methods. However, among the remaining studies that did explore the role of animal personality in husbandry, health, and welfare, we identified progression towards integrating personality data into various aspects of animal management. Evidence suggests the assessment of personality may benefit social group management, enrichment practices, training protocols, health and welfare monitoring, and conservation planning for endangered species. We argue that further research which develops our understanding of primate personality and its influence in these areas will provide a valuable tool to inform animal management practices. 
40

\section{Introduction}

42 Institutions which keep captive primates, whether as part of a zoological collection,

43 breeding facility or research laboratory, strive to continually improve welfare and

44 conditions for the animals in their care. One area of growing interest is incorporating

45 individual behavioural differences into management plans. Evidence suggests that

46 incorporating such differences could significantly improve management outcomes; for

47 example, personality is associated with breeding success and pair compatibility in black

48 rhinoceros (Carlstead et al. 1999). While species differences in behavioural responses

49 to captivity and management practices are recognised (Mason 2010) the predominant

50 focus in such approaches has been on behavioural differences related to age, sex, and

51 rank. However, with the advent of the $21^{\text {st }}$ century, the study of intraspecific behavioural

52 differences has become an increasingly explored area of applied behavioural science.

$53 \quad$ "Temperament" or "Personality" is broadly described as individual differences in

54 behavioural tendency that are consistent across time and contexts (Watters and Powell

55 2012). Each "personality trait", or "dimension", is defined by Eysenck (1997) as a

56 spectrum along which consistent individual differences in specific groups of behaviours

57 can be quantitatively measured (Itoh 2002). Primate personality dimensions are well

58 described; personality assessments are available for several species including

59 chimpanzees, gorillas, and rhesus macaques (Freeman and Gosling 2010). Personality

60 assessments in primates have been demonstrated to have construct validity (Freeman

61 and Gosling 2010), i.e. they measure what they purport to measure (Cronbach and

62 Meehl 1955; Campbell and Fiske 1959; Itoh 2002). Analyses of personality 
63

64

65

66

67

68

69

70

71

72

73

74

75

76

77 78

79

80

81

82

83

84

85

assessments have also been established as reliable (Freeman and Gosling 2010); that

is, consistent scores are produced when a subject is tested against the same

assessment multiple times or by different assessors (Itoh 2002).

The literature suggests that personality plays a role in influencing behaviour, social compatibility, health, and reproductive success of an array of taxa, not only primates (Tetley and O'Hara 2012), and so may provide information to inform management practices and, potentially, increase their effectiveness. While individual character traits are often recognised by those who work closely with animals and considered in management decisions (Watters and Powell 2012), investigating the potential of quantitative measurements of personality is still a new area of research.

Potential applications include and are not limited to tailoring enrichment programmes to reduce stress and stereotypic behaviour more effectively (Gartner and Powell 2012;

Franks et al. 2013; Hopper et al. 2014a), identifying individuals at higher risk of developing stress-related morbidities (Jin et al. 2013; Gottlieb et al. 2018), and improving the success of social introductions (Martin-Wintle et al. 2017).

While the possibilities are promising, practical application of individual personality data requires an understanding of the mechanisms by which personality predicts health and welfare outcomes. Despite primates being popular subjects of personality research (Freeman and Gosling 2010), the field has, historically, been fragmented (Tetley and O'Hara 2012). Published studies of primate personality encompass a broad spectrum of disciplines, including psychology, evolution, and zoology, which, while providing multiple perspectives, can make it challenging to synthesise their results. Bringing together this research is essential to prevent lines of investigation from becoming isolated (Tetley 
86

87

88

89

90

91

92

93

94

95

and O'Hara 2012) and to generalise findings for real-world application, i.e. to draw broad conclusions which extend to species or settings outside of those within individual studies (Polit and Beck 2010).

A previous review by Freeman and Gosling (2010) explored how the field of primate personality research has developed since the early 1900 s. While this review identified an increasing interest in, and acceptance of, the scientific study of personality in nonhuman primates, the authors highlighted gaps in the literature. Freeman and Gosling recommended that future study should aim to examine and realise the potential practical uses of personality to the management of primates. The last paper to synthesize the results of the primate personality literature in this way was by Coleman (2012), who identified that, while the use of personality assessments held promise in areas of captive management in guiding management decisions, additional research into how temperament can improve behavioural management would be necessary for personality to be included in captive management plans on a systematic level. Our review aims, over a decade on from Freeman and Gosling's initial review, to explore whether this knowledge gap has been addressed. In doing so, we aim to identify priority research directions in the hopes of facilitating effective incorporation of personality assessments into management practice in the future.

This review will adopt the following structure. We begin by describing the scope and methods of our literature survey. We then summarise the findings of that survey according to the species involved, the context (laboratory, zoo, and wild settings), the assessment methods used, and the research focus of the studies reviewed. In the following section, we discuss the findings of these studies in relation to five key 
109 applications in primate management, namely social management, environmental

110 enrichment, training protocols, health and welfare monitoring, and conservation

111 planning. We also consider some further directions for applied study that have received

112 little attention to date. Finally, we conclude with some brief recommendations.

\section{Survey Method}

115 The selection strategy chosen for this review followed the methodology outlined in

116 Freeman and Gosling's (2010) more general review of personality in nonhuman

117 primates, adapted where appropriate as outlined below. While this review primarily

118 focuses on implications for zoo animal management, we anticipate that our findings will

119 extend to primates in other contexts, such as laboratories and breeding facilities.

120 Therefore, our strategy aimed to encompass a variety of disciplines, so as not to miss

121 potentially relevant articles.

122

Keyword searches were conducted in a range of databases to ensure wide coverage. Databases used were ScienceDirect, Web of Science and PubMed.

124 Databases were searched for publications which included the terms "primate", along with "personality" or "temperament". For this review, searches included one of the terms "management", "conservation", or "welfare" (e.g; "primate AND personality AND management" or "primate AND temperament AND welfare"). These terms were included to ensure results produced articles relevant to this review. As pre-2010 studies were comprehensively included in Freeman and Gosling's (2010) review, and this review aimed to cover recent developments, searches were filtered only to include

131 studies published in or after 2010 and until 2020. The reference lists of selected 
132 publications were also checked for additional publications. Further articles which were

133 missed in initial searches that were brought to our attention were included where 134 relevant.

135 The abstracts of articles, after eliminating duplicates, were scanned to exclude 136 irrelevant papers. For most studies, it was straightforward to determine relevance by 137 abstract, title and keywords. Examples of irrelevant articles included: those which did 138 not refer to personality; studies on nonprimate taxa; nonhuman primate personality 139 studies that did not discuss management, welfare or conservation; and studies of 140 human personality. Furthermore, it was deemed that only peer-reviewed research 141 articles with published empirical data would be included; thus reviews, correspondence, 142 and conference abstracts which referred to unpublished data were excluded.

143 Full texts were appraised to refine the selection. Several studies which focused 144 primarily on mechanisms underlying personality (i.e. genetic and evolutionary factors) were excluded as being beyond the scope of this study. However, several studies which measured genetic and evolutionary components were retained on the basis that those

147 articles compared other variables against personality, such as health and welfare, and

148 thus remained relevant. Several items were excluded as personality was discussed very 149 minimally within the text and was not quantitatively measured.

150 Ultimately, 69 papers were selected for qualitative synthesis. Refer to Appendix 1 for 151 the full list of articles.

\section{Survey Findings}




\section{Species}

156 While there are around 400 extant primate species, only a small proportion is

157 represented in published personality literature. Across 69 studies, 28 species are

158 assessed, representing 17 genera (Fig. 1) - and only nine of the 16 extant primate

159 families. Of those 28 species, 13 were only included in one study. Within the genera

160 represented, there is a bias towards several more commonly studied species. For

161 example, while seven species within the genus Macaca are described across $27 \%$ of

162 studies, rhesus macaques (Macaca mulatta) are the subjects of almost half (43\%) of

163 those articles.

164 Across all studies, $41 \%$ were carried out on just five species (Fig. 2).

165 Chimpanzees (Pan troglodytes) were the most studied subject (16\%), followed by 166 rhesus macaques (Macaca mulatta, 12\%). Of these five taxa, only two are of

167 conservation concern (gorillas are Critically Endangered and chimpanzees are

168 Endangered; the remaining three species are least concern: IUCN 2020). While 143

169 species of primate are maintained in zoos (Melfi 2005), only 12 of these species were

170 represented in studies of zoo-housed primates (Figure 3). Several primate groups were

171 represented minimally or not at all, including but not limited to lemurs, howler and spider

172 monkeys, colobines and guenons, and gibbons, to name a few. This may be due to

173 methodological difficulties; for example, for smaller primates such as lemurs it can be

174 difficult to accurately identify individuals in behavioural research. Other primates, such

175 as gibbons, are less common in captive settings and difficult to study in the wild, and so

176 are less available as research subjects for personality studies. 


\section{Research Setting}

179 The highlighted studies were carried out on animals living in one of four settings. Zoo-

180 housed animals were the most common subjects (39\%), followed by laboratory (36\%)

181 and then free-living animals (25\%). One study was carried out on animals in a captive 182 open environment (1\%) within a wildlife sanctuary.

183

184

Assessment Method

185 The principal methodologies used to carry out personality assessments of nonhuman 186 primates can be divided into three categories; (i) behavioural coding, (ii) context tests, 187 and (iii) trait ratings (Table 1). While trait rating was the most common method used by 188 studies, within this category there are a number of commonly used trait rating 189 instruments. Notably, the Hominoid Personality Questionnaire (HPQ) (Weiss 2009; 1902017 ) was the most commonly used tool (58\% of trait rating studies). Refer to Appendix 1912 for a full list of trait rating instruments.

192 Each method has benefits and drawbacks (Powell and Gartner 2011; see 193 Appendix 3). Some studies (30\%) used a combination of methods to validate results 194 and overcome some of the drawbacks associated with each process. Studies which 195 combined behavioural coding and trait rating were more common (16\%), followed by 196 combining context tests with trait rating (9\%).

\section{Research Focus}

Across the reviewed personality literature, five key areas of investigation emerged. The

first was method validation, while the remainder explored the role of personality in social 
201 behaviour, animal health, animal welfare, and animal management. Each study could 202 be categorised into one of these five areas, as outlined in Table 2. Method validation 203 was the most commonly studied single category $(42 \%)$, with several studies focusing on 204 assessing species which had not been studied before (e.g., Pritchard et al. 2014), and 205 others on producing new assessment methods (e.g., Freeman et al. 2013; Masilkova et 206 al. 2018). The remaining personality studies accounted for $58 \%$ of the reviewed literature. Studies of the role of personality in social behaviour were the most common within this 209 group (22\%, Table 3). These studies reported a variety of effects: a total of 27 response variables were tested against personality, of which $85 \%$ showed a statistically significant 211 relationship, such as relationship stability (Weinstein and Capitanio 2012) and 212 relationship quality (Morton et al. 2015).

213 The next most frequently identified category concerned personality and 214 management practices (17\%; Table 4). Across 25 response variables, $80 \%$ had a 215 statistically significant relationship with personality, such as training success (Reamer et 216 al. 2014; Wergård et al. 2016) and enrichment use (Franks et al. 2013; Lutz and Brown 217 2018).

218 In the final two categories, welfare (10\%; Table 5) and health (9\%; Table 6), the 219 studies primarily addressed well-being concerns, such as stress. Welfare studies 220 primarily examined behavioural indicators of stress such as stereotypies (Vandeleest et 221 al. 2011; Robinson et al. 2016, 2017), while health studies examined stress-related 222 morbidity risk (Fernandez and Timberlake 2008; Gottlieb et al. 2018; Robinson et al. 
223 2018). Notably, only one study examined personality and health status in a wild 224 population (Costa et al. 2020).

225

226

227 228 229 230 231

232 233 234 235 236

\section{Applications to Primate Management}

While rudimentary descriptions of animal personality traits have long been informally recognised (Watters and Powell 2012), the past decade has seen increasing scientific recognition that consistent individual differences exist, are measurable, and impact individual and population-level management outcomes. However, this review identified that research to date continues to focus on the validation of new assessment methods and, by comparison, researchers have explored the links between personality and management outcomes in less detail. It is also notable that the taxonomic coverage in the field is biased towards well-studied primates which already have validated assessments, while research on other taxa - such as lemurs, gibbons, and howler monkeys, to name a few - is limited to descriptive studies or non-existent. This is despite the potential benefits of understanding personality in the management of species which are commonly found in collections or are of high conservation priority. Furthermore, the potential of personality assessments as a management tool is still in need of exploration before they can be widely applied.

We now extend our review to the discussion of the key findings of the identified personality studies, with specific focus on how the knowledge base could be incorporated into primate management practices. Through this review, we identified five major research focuses: method validation, social behaviour, management, welfare and health. However, as each category is broad, covering a variety of possible applications, 
246 for the purposes of this discussion it was elected to highlight more specific areas of

247 management practice which the identified studies could inform. The following five key

248 areas emerged, namely environmental enrichment, training protocols, health and

249 welfare monitoring, and conservation planning.

250

251 Social Management

252 The link between social behaviour and personality has been a recent focus of several

253 studies (Table 2, 3). The development and maintenance of social bonds are essential

254 aspects of primate behaviour, and most species form social groups in the wild

255 (Lehmann et al. 2007). Housing primates in social groups which mimic those of their

256 wild conspecifics confers considerable benefits: promoting naturalistic behaviour

257 budgets, providing mental stimulation, and reducing stress (Kleiman et al. 2012);

258 however, it also comes with risks. For example, species which would normally live in

259 multimale groups in the wild are generally exhibited in single-male groups for breeding

260 purposes and to manage aggression (Schapiro 2017). Furthermore, facilities often need

261 to move individuals between breeding groups; social disruptions, when unsuccessful,

262 can result in physical injury and compromised psychological health (Kleiman et al. 2012;

263 Brando and Buchanan-Smith 2018). Coleman (2012) proposed that personality

264 assessments may be used by managers to guide socialization choices in captive 265 primates.

266 The risk of injury due to conspecific aggression is a key consideration for primate

267 managers, so an ability to predict the risk of aggression from personality could be very

268 useful. In a recent study, Robinson et al. found that rhesus macaques, which were 
269 housed in recently established social groups, which rated as either low in Confidence or 270 low in Anxiety presented with significantly more injuries (Robinson et al., 2018).

271 Personality was associated with the number of injuries even when controlling for

272 kinship, rank, and sex. These results seem to indicate that individuals higher or lower in 273 particular personality traits are at higher risk of experiencing aggression when placed in 274 new groups. Alternatively, personality could predict the individuals more likely to 275 instigate aggression. The relationship between personality and aggressive and 276 antisocial behaviour is well-described in the human literature; particularly, low 277 Agreeableness, low Conscientiousness and high Neuroticism contribute to aggression 278 in studies of humans (Jones et al. 2011). However, too few studies systematically 279 address the relationship between personality and aggressive behaviour to form a 280 meaningful conclusion in nonhuman primates; while low 'Understanding' was 281 associated with higher aggression in one bachelor group of four gorillas (Račevska and 282 Hill 2017), the sample size was too small to control for factors such as social rank.

283 While further studies into nonhuman primates would be necessary to confirm the 284 relationship between personality and aggression, the current findings on aggression and 285 injury in both humans and primates could have potential implications for social 286 management decisions. For example, individuals higher or lower in traits related to 287 aggression may require different introduction protocols to reduce the likelihood of injury. 288 It would be interesting for future research to examine whether the same personality 289 dimensions which influence aggressive behaviour in humans are of importance in 290 predicting aggression in nonhuman primates. 
Conversely from aggression, recent research suggests that certain personality

292

293

dimensions may play an important role in the formation and maintenance of primate social bonds. One study of rhesus macaques found that personality data collected up to 10 years prior was associated with later pair success, with successful pairs being those which actively sought each other's company and did not show fear or aggression outside of feeding (Capitanio et al. 2017). These results suggest that personality data collected by keepers could be used long-term to aid in forming new social groups by matching personality types. A 'Sociability' dimension has been described in multiple primate species (Freeman and Gosling 2010; Freeman et al. 2013; Morton, Lee, Buchanan-Smith, et al. 2013; Pritchard et al. 2014; Martin and Suarez 2017). Primate Sociability is associated with adjectives such as "Helpful" and "Sociable" (King and Figueredo 1997) and corresponds with a range of behaviours including proximity, grooming, and play (Koski 2011). A study by Morton et al. (2015) found that captive capuchin (Sapajus spp.) dyads who were more similar in the Sociability dimension, had higher-quality relationships. Similar findings in bonobos (Verspeek et al. 2019), chimpanzees (Massen and Koski 2014) and Assamese macaques (Ebenau et al. 2019) suggest that personality dimensions related to social behaviour may play an important role in the development of stronger social bonds. Overall, these results indicate that individuals which are more sociable seem to demonstrate a preference for animals which are similarly sociable; at the other end of the scale, individuals which are less sociable generally appear to prefer being with similarly less sociable conspecifics. In addition to individual dyadic relationships, individual personalities will also influence the social network (Seyfarth et al. 2014). For example, research by McCowan 
314 et al. (2011) found that high-ranking rhesus macaque males rated as higher in Equable

315 were more successful interveners; and that successful third-party intervention resulted

316 in more stable social networks, less wounding, and higher rates of post-conflict

317 reconciliation. However, social networks are also influenced by rank and kinship

318 (Seyfarth et al. 2012, 2014). One study of laboratory-housed rhesus macaques

319 identified sex and relatedness as being just as essential predictors of relationship 320 stability as personality homophily (Weinstein and Capitanio 2012). The importance of

321 relatedness is corroborated by research on wild female chacma baboons, where

322 personality homophily was only significant in predicting the relationship strength of

323 closely related siblings; personality was not a predictor of relationship quality in

324 unrelated pairs, where similarities in age and rank were more significant (Seyfarth et al.

325 2014). Consequently, the extent to which personality would aid management,

326 particularly for large groups and unrelated individuals, is called into question. It would be

327 useful for future research to examine whether personality variables impact the success

328 with which new individuals are introduced into captive social groups. While

329 experimentally manipulating social groups of primates with limited populations,

330 especially endangered species, is not possible in many cases, retroactive examination

331 of group success for animals which can have their personalities assessed could still be 332 instructive.

333 Overall, these results suggest that while various aspects of an individual's

334 personality may be used to guide social management decisions in primates, caution

335 should be exercised to avoid over-simplified generalisations. While personality data

336 provides additional information to consider during social management and serves as an 
337 additional tool in predicting the outcome of decisions, it remains imperative, and more

338 feasible, to consider all characteristics of the individuals involved including age, sex,

339 rank, and relatedness.

340

341 Environmental Enrichment

342 Environmental enrichment is a crucial component of many animal husbandry

343 programmes. Enrichment promotes welfare by encouraging species-typical behaviour,

344 and challenging animals both mentally and physically (Gartner and Weiss 2018) and

345 comes in several forms, providing unique opportunities to forage, explore and

346 manipulate their environment (Hosey et al. 2013). However, enrichment does not

347 consistently improve welfare for all individuals; one study of common squirrel monkeys

348 (Saimiri sciureus) identified consistent individual differences in the extent of welfare

349 improvement under different enrichment conditions, which were unexplained by sex or

350 age (Izzo et al. 2011). A possible explanation for these consistent individual differences

351 is that they are reflections of personality. Correlations between personality and

352 behaviour towards enrichment objects have been recently described in snow leopards

353 (Panthera unca) (Gartner and Powell 2012), which suggests that accounting for

354 personality could, in theory, improve enrichment efficiency. However, the link between

355 personality and enrichment success is understudied in primates. To date, only one

356 paper, published prior to 2010 and therefore not included in our analysis, provides

357 evidence that enrichment plans based on personality have tangible welfare benefits for

358 primates (Highfill 2008). Studying a small group of Garnett's bushbabies (Otolemur 
359

360

361

362

363

364 365

garnettii), Highfill found that enrichment interventions designed to reflect personality dimensions resulted in significant reductions in stereotypic behaviour.

The limited research on personality and enrichment across primate and nonprimate taxa is restricted to restrictive comparisons of just one or two personality dimensions and small subsets of behaviours. While novel objects are often used in assessments designed to measure certain personality components, such as the 'Shy Bold' continuum (Verdolin and Harper 2013; Šlipogor et al. 2016; Ferfnández-Lázaro et al. 2019), the effect is rarely described in the context of enrichment effectiveness. Furthermore, while associations between 'Shy - Bold' and novel object approach are described, the effectiveness of other common enrichment interventions - such as scatter feeding, training, puzzle toys etc. - may rely on different dimensions of personality (Highfill 2008). Consequently, studying the interaction between personality and enrichment may be difficult to apply across settings. Franks et al. (2013) suggest that animals display an individual preference for 'promotion' (rewards-motivated) or 'prevention' (safety-motivated) based on the 'regulatory focus' personality theory (Higgins 1997). In their study, the authors compared behaviour-coded regulatory focus personalities against latency to approach different enrichment items for four zoo-housed cotton-top tamarins (Saguinus oedipus) and found significant correlations between personality and enrichment approach. While the small sample size limits how far the results can be generalised, the results demonstrate how personality can be used to successfully predict how individuals approach enrichment in a small collection.

However, the relationship between personality and enrichment intervention success remains unclear. It would be beneficial for researchers to further explore the impact of 
382 personality on enrichment success, including whether the results demonstrated by

383 Highfill (2008) can be replicated in other primate species. Personality assessments

384 could then be used to produce enrichment protocols which are tailored to the 385 individuals.

386

387 Training Protocols

388 Training has a multitude of benefits and is a staple component of many primate 389 management programmes. Training provides mental stimulation and thus is a form of 390 enrichment (Melfi et al. 2020), and animals can voluntarily participate in common 391 management procedures, such as veterinary examinations, without the need for more 392 invasive methods of restraint (Reamer et al. 2014). However, while some animals are 393 eager to participate and learn quickly, others can struggle to pick up the same tasks or 394 are more reluctant to engage in training (Melfi et al. 2020). Two studies have found that 395 Openness predicts participation in training sessions in chimpanzees (Herrelko et al. 396 2012; Reamer et al. 2014; Altschul et al. 2017), and similar findings have been reported 397 in other species (Altschul et al. 2016). A recent study of long-tailed macaques (Macaca 398 fascicularis) demonstrated that high scores on Activity, a dimension similar to 399 chimpanzee Openness, correlated with a decrease in the number of approximations 400 required to successfully train new behaviours (Wergård et al. 2016). In another study, 401 squirrel monkeys rated as low on 'Cautiousness' and high on 'Playful', 'Gentle',

402 'Affectionate' and 'Friendly' were more likely to participate in research procedures 403 (Polgár et al. 2017). These results have implications for training programmes; 
404 personality data could be used to identify which individuals to target for training first 405 versus those which may require additional support or alternative training methods. In their review of great ape personality research, Gartner and Weiss (2018) 407 suggest that more confident animals may act as positive role models for those which 408 are shyer and more reluctant to train. It may therefore be beneficial to examine the 409 effect of personality on cue-response latency, or the time it takes for a target animal to complete a desired behaviour upon being given a verbal or visual command by a

411 trainer, to determine which individuals are best suited as conspecific trainers for other 412 individuals. In a multi-institution and cross-species study, Ward and Melfi (2013)

413 measured cue-response latency in 12 Sulawesi crested macaques (Macaca nigra), 8 414 black rhinoceros (Diceros bicornis), and 11 Chapman's zebra (Equus burchellii) and compared results against keeper-rated behavioural profiles. While the authors highlight

416 that the fastest response times were from 'Bold' dominant monkeys in two of the three

417 macaque groups, the pattern identified is anecdotal and the relationship between

418 personality and latency was not found to be significant. However, only three groups of 419 each species were assessed, and groups varied in their level of past training experience 420 from completely untrained to fully trained. When compared with nonprimate taxa, social 421 species responded significantly faster than solitary species (Ward and Melfi 2013), 422 which may imply that social learning facilitates better performance during training.

423 Directed social learning, where individuals preferentially learn from specific 424 demonstrators, has been described in captive chimpanzees (Kendal et al. 2015) and 425 wild vervet monkeys (Chlorocebus pygerythrus) (Grampp et al. 2019; Canteloup et al. 426 2020), which are described with a preference for observing dominant animals. However, 
427 it is yet unexplored whether primates demonstrate a preference for particular

428 personalities in demonstrators, despite evidence suggesting that personality may play a

429 role in social learning. A recent study of cooperation in free-living Barbary macaques

430 (Macaca sylvanus) noted that 'Shy' subjects, while less likely to approach a novel test

431 apparatus, maintained cooperation for longer when working with bold individuals

432 (Molesti and Majolo 2016). Carter et al. (2014) found that chacma baboons rated as

433 'Anxious' showed greater improvement in completing problem-solving tasks after

434 observing experienced conspecific demonstrators. While past research has primarily

435 focused on training and personality at the individual level, in light of these findings,

436 future studies could explore the group-level impacts of personality and whether the

437 presence of bold partners significantly influences training success of shyer primates.

438

439 Health and Welfare Monitoring

440 The maintenance of physically and mentally healthy animals is a key aspect of primate

441 management. Studies have found links between personality and these areas (Table 5,

442 6); for example, personality has been linked to longevity in captive primate species such

443 as chimpanzees (Altschul et al. 2018) and gorillas (Weiss et al. 2013). However, there is

444 little evidence to suggest personality alone predisposes individuals to specific health

445 outcomes (Jin et al. 2013; Robinson et al. 2018); instead, the recent literature suggests

446 personality influences health when interacting with factors such as environment and

447 stress (Gottlieb et al. 2018). This relationship would suggest that when faced with

448 stressful events, such as relocating enclosures, specific individuals may have a lower

449 stress tolerance threshold and thus are more vulnerable to stress-related illness. For 
450 example, a recent study by Gottlieb et al. (2018) found that, while personality did not 451 predict an individual's risk of acute diarrhoea after a housing relocation, more 'Nervous' 452 and 'Gentle' monkeys were more likely to experience chronic diarrhoea. An additional 453 study of golden snub-nosed monkeys (Rhinopithecus roxellana), an endangered 454 species at high risk of gastrointestinal disorders due to their specialist diet, found a 455 significant relationship between personality and morbidity. Lower Aggressiveness was 456 related to greater incidence of illness, longer illness duration, and poorer digestive 457 function (Jin et al. 2013). Understanding how personality influences stress has 458 implications for primate welfare and health management; for example, it may be possible to promote longevity through understanding specific animals' limits for stress 460 and identifying individuals at high risk of developing stress-related illnesses. Resources can then be allocated to focus preventative measures on individuals predisposed to poor health outcomes, and potentially stressful management interventions can be avoided or minimised for those individuals. challenges to animal caretakers. Welfare is, typically, measured with one or a combination of methods; behavioural indicators, such as stereotyped behaviour, and 467 physiological measures, such as cortisol, are commonly utilised indices (Hosey et al. 468 2013). However, correlations between these variables are not always consistent, even within the same species (Fernández-Lázaro et al. 2019); consequently, animal caretakers may inadvertently over- or under-estimate welfare. Studying personality may

471 aid in understanding why behavioural and physiological measures are not always 472 consistent measures of welfare; for example, recent studies have suggested that 
473 individuals may rely on different coping strategies and display alternative stress-

474 indicative behaviours (Ferreira et al. 2018). However, while several studies have

475 highlighted personality as an intrinsic factor predisposing individuals to developing 476 stereotyped behaviours, they typically focus on only one type of behaviour. Recent 477 research by Robinson et al. $(2016,2017)$ which found associations between primate 478 personality and psychological health, for example, relied on motor stereotypies to 479 generate welfare scores. Similarly, while Gottlieb et al. (2013) identified a relationship 480 between life history and personality in predicting motor stereotyped behaviour (i.e., 481 pacing) and self-injurious behaviour risk, the authors acknowledge that the absence of 482 such behaviours does not necessarily indicate "positive" welfare. Indeed, for some 483 animals, inactivity or unresponsiveness could be less preferable than pacing from a 484 welfare perspective, and yet in the aforementioned studies may have scored as having 485 higher welfare. Only one study explored how traditional welfare measures may be impacted by personality. Ferreira et al. (2018) aimed to quantitively measure the hormonal correlates 488 of personality types and specific stress-indicative behaviours under stress in 25 zoo489 housed brown capuchins. The 'Active' personality dimension was found to be of 490 particular significance in this study; monkeys assessed as more 'Active' displayed more 491 rapid stereotyped behaviours, such as pacing head-twirling, and exhibited higher faecal 492 glucocorticoid metabolite (FGM) levels (Ferreira et al. 2018). 'Active' was similarly 493 reported to predict FGM in an assessment carried out by Fernández-Lázaro et al. 494 (2019) on eight primate species (S. oedipus, Saguinus imperator, Leontopithecus 495 rosalia, Callithrix jacchus, Callithrix geoffroyi, Cebuella pygmaea, Pithecia pithecia, 
496 Nycticebus pygmaeus). In contrast, less 'Active' animals were more likely to display 497 prolonged state stereotyped behaviours, such as self-scratching and inertia (Ferreira et 498 al. 2018). Understanding individual variation in stress coping styles would aid in explaining the incongruity between measures of welfare and would support primate 500 caretakers in recognising signs of poor welfare in their animals.

501

Robinson et al. (2017) suggest that a subjective approach to measuring welfare, 502 in combination with traditional measurements such as stress-indicative behaviours and 503 hormone levels, provides a quick and easy method to measuring welfare which 504 considers personality. Comparisons of caretaker-rated subjective well-being scores and 505 personality have highlighted dimensions of potential relevance. High Neuroticism was a 506 predictor of low welfare in studies of chimpanzees (Robinson et al. 2017), capuchins

507 (Robinson et al. 2016) and marmosets (Inoue-Murayama et al. 2018), while high

508 Dominance was related to better welfare in male gorillas (Schaefer and Steklis 2014).

509 Equipped with the knowledge that particular personality dimensions influence the risk of 510 poor welfare, and that certain indicators may be more relevant for particular individuals, 511 primate keepers can identify at-risk animals and monitor them more closely. It would be 512 particularly beneficial to establish individual behavioural baselines so that dramatic 513 changes unusual for a specific animal are easy to identify.

514

\section{Conservation Planning}

516 For endangered species which are bred in captivity, conservation plans may consider

517 eventual reintroduction of captive populations into the wild, or translocation of free-living 518 populations to new areas. Hosey et al. (2013) highlight how personality is, increasingly, 
519 coming to be appreciated for its contribution to the success of such initiatives. There is

520 rising concern that captive breeding programmes which ignore personality are

521 inadvertently reducing the diversity of behavioural traits which contribute to survival

522 (McDougall et al. 2006). An area of literature suggests that personality has a genetic

523 component (e.g., Adams et al. 2012; Inoue-Muruyama et al. 2018) and up to 50\% of

524 personality variation, depending on the species, is heritable (van Oers et al. 2005;

525 Dochtermann et al. 2015). Therefore, breeding to select for high boldness may be

526 beneficial for captive populations as bold animals may be less likely to suffer adverse

527 reactions to the presence of human caretakers and visitors (Stoinski et al. 2012;

528 Verdolin and Harper 2013; Polgár et al. 2017). In the wild, however, bolder animals may

529 be more likely to engage in risky behaviour, such as approaching unfamiliar humans or

530 predators, which could compromise the likelihood of survival (Dammhahn and Almeling

531 2012).

532 Personality may impact survivorship and fitness of wild populations in several

533 ways. For example, there is evidence to suggest that personality influences antipredator

534 responses in free-living primates. Blaszczyk (2017) assessed whether experimental

535 assays of Boldness could predict antipredator response to both natural and artificial

536 novel predators in wild vervet monkeys. In this study, a Boldness score generated after

537 three novel object tests correlated with exploratory risk-taking behaviour when faced

538 with a predator stimulus; bolder monkeys were more likely to approach and inspect both

539 novel and natural predators (Blaszczyk 2017). These results suggest that certain

540 individuals may be less suitable to reintroductions based on their personality. While

541 there has yet to be a quantitative assessment of personality and reintroduction success 
542 of primates, a study of captive-bred swift foxes (Vulpes velox) found that individuals

543 assessed as Bold had decreased likelihood of survival in the first six months post-

544 release (Bremner-Harrison et al. 2004). Selecting candidates for release based on their

545 personality should, therefore, increase the success of reintroductions.

$546 \quad$ However, taking a one-size fits all approach for applying personality to

547 reintroductions may prove to be too simplistic. As Boldness is naturally present in wild

548 populations, it must be associated with benefits to have evolved. It is possible that

549 removing the dimension in reintroduced groups - while potentially improving initial

550 survivorship - could have unforeseen impacts on other aspects of wild living. For

551 example, bolder animals may be more inclined to explore foraging areas for new food

552 patches; for instance, Costa et al. (2020) found that in wild golden-headed lion tamarins

553 (Leontopithecus chrysomelas) high 'Confidence' was significantly correlated with more

554 time spent foraging and higher body mass. Furthermore, Carter et al. (2012) argued that

555 the traditional methods used for measuring Boldness in wild populations, such as

556 predator tests and novel food tests, inconsistently measure the personality dimensions

557 relevant for survival. The authors recorded individual responses to both a novel predator

558 test and a novel food test for 57 wild baboons and examined correlations between the

559 results of both assays. Interestingly, the animals which showed the greatest alarm

560 response to the novel predator - and thus scored as low in Boldness - inspected the

561 item for longer and scored higher on Boldness in the food test (Carter et al. 2012).

562 Consequently, it was determined that one of the assays must have been measuring a

563 different personality dimension than Boldness. It should be recognised that multiple

564 personality dimensions contribute to the long-term success of primate reintroductions. It 
565 would be beneficial to carefully monitor reintroductions for animals of a range of

566 personality types to fully assess which dimensions are associated with positive

567 outcomes.

568

569 Further Directions for Applied Study

570 There are several further areas of interest where personality could be used to guide and 571 improve primate management but have received little or no attention to date. The first is

572 the relationship between personality and reproductive success. Seyfarth et al. (2012)

573 introduced this concept by suggesting that personality is connected to social measures

574 which influence reproductive success in wild baboons, however, the topic was not

575 extensively discussed in the reviewed literature otherwise. The relationship between

576 personality and reproductive success has nonetheless been documented in several

577 species, including humans (Berg et al. 2014). For example, a 1999 study of captive

578 cheetahs found that individual behavioural differences were associated with breeding

579 status (Wielebnowski 1999). A similar relationship was identified in captive black

580 rhinoceros (Carlstead et al. 1999). These findings suggest that certain personality traits

581 are correlated with higher reproductive success in captivity, information which would be

582 beneficial to breeding programmes of species which have historically been difficult to

583 breed in the zoo environment. Furthermore, Powell and Gartner (2011) suggested that

584 personality may play a role in mate selection. A relationship between personality and

585 mate compatibility has been described in giant pandas (Martin-Wintle et al. 2017) but no

586 research has yet examined this relationship in nonhuman primates. As information

587 regarding the reproductive success of primates in captivity is readily available through 
588 studbook coordinators and similar avenues, comparisons between personality and 589 reproductive status, pair success, fertility and other variables would be straightforward 590 for future studies to explore.

591 Second, personality could be used to decide which animals are most suitable for 592 visitor education experiences in zoos, such as walk-through exhibits or meet-and593 greets. While this possibility has not been quantitatively explored, Polgár et al. (2017)

594 found that more Playful and less Solitary and Cautious squirrel monkeys were 595 significantly more likely to approach a visitor viewing window under high crowd 596 conditions, which suggests that certain personality types may be more comfortable with 597 unfamiliar human presence. This effect might also extend to the human keepers of 598 animals and human-animal interactions in general.

599

\section{Conclusions}

601 Accumulating evidence suggests that there can be important links between an

602 individual's personality and its social behaviour, management, welfare and health, and 603 that incorporating these links into captive breeding and conservation programmes could 604 lead to more successful and positive outcomes. On this basis, we make the following 605 recommendations:

1. Research focus within the field of primate personality research should shift away from the development and validation of more personality tools and instead 608 towards (i) standardising common tools, such as the Hominoid Personality Questionnaire, for use across taxa, and (ii) making such standardised tools easier to implement on a wide scale. It would be beneficial to assess whether 
611

612

613

614

615

\section{1}

personality assessments validated at the family level are adequate for use across all genera and species within that family. These assessments will also need to be validated for use in understudied primate groups - including, but not limited to, tarsiers, lemurs, howler monkeys, night monkeys, langurs, and gibbons - to facilitate the following recommendations for a wider range of species.

2. Wider species management initiatives (e.g. EAZA ex-situ programmes) should encourage participating facilities to carry out personality assessments. Larger samples of personality data collected across multiple institutions could prove a valuable resource for co-ordinated breeding programmes, as well as providing the scope for longitudinal and retrospective studies.

3. Future study should address key gaps in the primate personality literature; particularly (i) regarding taxa which are currently underrepresented in studies and (ii) exploring the links between personality and health, welfare, social management, and other practical areas of interest in greater detail. Further areas of interest include the relationship between personality and reproductive success and human-animal interactions.

\section{Acknowledgements}

We are grateful to Louise Barrett, Alexander Weiss, and an anonymous reviewer for their very helpful comments on this paper.

.

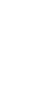




\section{References}

635 Adams, M.J., King, J.E., Weiss, A. (2012) 'The majority of genetic variation in orangutan

636 personality and subjective well-being is nonadditive', Behavior Genetics, 42(4), 675637686.

638 Adams, M.J., Majolo, B., Ostner, J., Schülke, O., De Marco, A., Thierry, B., Engelhardt, 639 A., Widdig, A., Gerald, M.S., Weiss, A. (2015) 'Personality structure and social style in 640 macaques', Journal of Personality and Social Psychology, 109(2), 338-353.

641 Altschul, D.M., Hopkins, W.D., Herrelko, E.S., Inoue-Murayama, M., Matsuzawa, T., 642 King, J.E., Ross, S.R., Weiss, A. (2018) 'Personality links with lifespan in chimpanzees', 643 eLife, 7, available: https://www.ncbi.nlm.nih.gov/pmc/articles/PMC6177254/ [accessed 4 644 Jul 2020].

645 Altschul, D.M., Terrace, H.S., Weiss, A. (2016) 'Serial Cognition and Personality in 646 Macaques', Animal Behaviour and Cognition, 3(1), 46-64.

647 Altschul, D.M., Wallace, E.K., Sonnweber, R., Tomonaga, M., Weiss, A. (2017)

648 'Chimpanzee intellect: personality, performance and motivation with touchscreen tasks', 649 Royal Society Open Science, 4(5), 170169.

650 Baker, K.R., Lea, S.E.G., Melfi, V.A. (2015) 'Comparative Personality Assessment of 651 Three Captive Primate Species: Macaca nigra, Macaca sylvanus, and Saimiri sciureus', 652 International Journal of Primatology, 36(3), 625-646.

653 Berg, V., Lummaa, V., Lahdenperä, M., Rotkirch, A., Jokela, M. (2014) ‘Personality and 654 long-term reproductive success measured by the number of grandchildren', Evolution 655 and Human Behavior, 35(6), 533-539. 
656 Blaszczyk, M.B. (2017) 'Boldness towards novel objects predicts predator inspection in 657 wild vervet monkeys', Animal Behaviour, 123, 91-100.

658 Brandão, A., Costa, R., Rodrigues, E., Vicente, L. (2019) 'Using behaviour observations 659 to study personality in a group of capuchin monkeys (Cebus apella) in captivity', 660 Behaviour, 156(3-4), 203-243.

661 Brando, S., Buchanan-Smith, H.M. (2018) 'The 24/7 approach to promoting optimal 662 welfare for captive wild animals', Behavioural Processes, Optimal Animal Welfare:

663 Evidence-based Standards and Practices, 156, 83-95.

664 Bremner-Harrison, S., Prodohl, P.A., Elwood, R.W. (2004) ‘Behavioural trait 665 assessment as a release criterion: boldness predicts early death in a reintroduction 666 programme of captive-bred swift fox (Vulpes velox)', Animal Conservation, 7(3), 313667320.

668 Canteloup, C., Hoppitt, W., van de Waal, E. (2020) 'Wild primates copy higher-ranked 669 individuals in a social transmission experiment', Nature Communications, 11(1), 459.

670 Capitanio, J.P., Blozis, S.A., Snarr, J., Steward, A., McCowan, B.J. (2017) ‘Do "birds of 671 a feather flock together" or do "opposites attract"? Behavioral responses and 672 temperament predict success in pairings of rhesus monkeys in a laboratory setting', 673 American Journal of Primatology, 79(1), e22464.

674 Capitanio, J.P., Mendoza, S.P., Mason, W.A., Maninger, N. (2005) 'Rearing 675 environment and hypothalamic-pituitary-adrenal regulation in young rhesus monkeys 676 (Macaca mulatta)', Developmental Psychobiology, 46(4), 318-330.

677 Campbell, D.T., Fiske, D.W. (1959) 'Convergent and discriminant validation by the 678 multitrait-multimethod matrix', Psychological Bulletin, 56(2), 81-105. 
679 Carlstead, K., Mellen, J., Kleiman, D.G. (1999) 'Black rhinoceros (Diceros bicornis) in 680 U.S. zoos: I. individual behavior profiles and their relationship to breeding success', Zoo 681 Biology, 18(1), 17-34.

682 Carter, A.J., Marshall, H.H., Heinsohn, R., Cowlishaw, G. (2012) 'How not to measure 683 boldness: novel object and antipredator responses are not the same in wild baboons', 684 Animal Behaviour, 84(3), 603-609.

685 Carter, A.J., Marshall, H.H., Heinsohn, R., Cowlishaw, G. (2014) 'Personality predicts 686 the propensity for social learning in a wild primate', PeerJ, 2, available:

687 https://www.ncbi.nlm.nih.gov/pmc/articles/PMC3961137/ [accessed 13 Jun 2020].

688 Coleman, K. (2012) 'Individual differences in temperament and behavioral management 689 practices for nonhuman primates', Applied Animal Behaviour Science, Special Issue:

690 The Welfare of Laboratory Primates, 137(3), 106-113

691 Costa, T., Nogueira-Filho, S., Vleeschouwer, K., Oliveira, L., Sousa, M., Mendl, M., 692 Catenacci, L., Nogueira, S. (2020) 'Individual behavioral differences and health of 693 golden-headed lion tamarins (Leontopithecus chrysomelas)', American Journal of 694 Primatology, 82.

695 Cronbach, L.J., Meehl, P.E. (1955) 'Construct validity in psychological tests', 696 Psychological Bulletin, 52(4), 281-302.

697 Dammhahn, M., Almeling, L. (2012) 'Is risk taking during foraging a personality trait? A 698 field test for cross-context consistency in boldness', Animal Behaviour, 84(5), 11316991139. 
700 Dochtermann, N.A., Schwab, T., Sih, A. (2015) 'The contribution of additive genetic 701 variation to personality variation: heritability of personality', Proceedings. Biological 702 Sciences, 282(1798), 20142201.

703 Ebenau, A., von Borell, C., Penke, L., Ostner, J., Schülke, O. (2019) ‘Personality 704 homophily affects male social bonding in wild Assamese macaques, Macaca 705 assamensis', Animal Behaviour, 155, 21-35.

706 Ebenau, A., Von Borell, C., Penke, L., Ostner, J., Schülke, O. (2019) ‘ntegrative 707 personality assessment in wild Assamese macaques (Macaca assamensis)', Journal of 708 Comparative Psychology, 134(1).

709 Eckardt, W., Steklis, H.D., Steklis, N.G., Fletcher, A.W., Stoinski, T.S., Weiss, A. (2015)

710 'Personality dimensions and their behavioral correlates in wild Virunga mountain gorillas

711 (Gorilla beringei beringei)', Journal of Comparative Psychology, 129(1), 26-41.

712 Eysenck, H. (1997) Dimensions of Personality, 1st edition. ed, Transaction Publishers:

713 New Brunswick, N.J.

714 Fernandez, E.J., Timberlake, W. (2008) 'Mutual benefits of research collaborations

715 between zoos and academic institutions', Zoo Biology, 27(6), 470-487.

716 Fernández-Lázaro, G., Latorre, R., Alonso-García, E., Barja Núñez, I. (2019)

717 'Nonhuman primate welfare: Can there be a relationship between personality,

718 lateralisation and physiological indicators?', Behavioural Processes, 166.

719 Ferreira, V.H.B., Silva, C.P.C.D., Fonseca, E.D.P., Chagas, A.C.C.S.D., Pinheiro, 720 L.G.M., Almeida, R.N.D., Sousa, M.B.C. de, Silva, H.P.A.D., Galvão-Coelho, N.L.,

721 Ferreira, R.G. (2018) 'Hormonal correlates of behavioural profiles and coping strategies 
722 in captive capuchin monkeys (Sapajus libidinosus)', Applied Animal Behaviour Science, $723207,108-115$.

724 Franks, B., Reiss, D., Cole, P., Friedrich, V., Thompson, N., Higgins, E.T. (2013)

725 'Predicting how individuals approach enrichment: Regulatory focus in cotton-top

726 tamarins (Sanguinus oedipus)', Zoo Biology, 32(4), 427-435.

727 Freeman, H.D., Brosnan, S.F., Hopper, L.M., Lambeth, S.P., Schapiro, S.J., Gosling, 728 S.D. (2013) 'Developing a Comprehensive and Comparative Questionnaire for

729 Measuring Personality in Chimpanzees Using a Simultaneous Top-Down/Bottom-Up

730 Design', American Journal of Primatology, 75(10).

731 Freeman, H.D., Gosling, S.D. (2010) 'Personality in nonhuman primates: a review and 732 evaluation of past research.', American Journal of Primatology, 72(8), 653-671.

733 Garai, C., Weiss, A., Arnaud, C., Furuichi, T. (2016) 'Personality in wild bonobos (Pan 734 paniscus)', American Journal of Primatology, 78(11), 1178-1189.

735 Gartner, C.M., Powell, D. (2012) 'Personality assessment in snow leopards (Uncia 736 uncia)', Zoo Biology, 31(2), 151-165.

737 Gartner, M.C., Weiss, A. (2018) 'Studying primate personality in zoos: implications for

738 the management, welfare and conservation of great apes', International Zoo Yearbook, 739 52(1), 79-91.

740 Gottlieb, D.H., Capitanio, J.P., McCowan, B. (2013) 'Risk factors for stereotypic

741 behavior and self-biting in rhesus macaques (Macaca mulatta): animal's history, current 742 environment, and personality', American Journal of Primatology, 75(10), 995-1008. 
743 Gottlieb, D.H., Del Rosso, L., Sheikhi, F., Gottlieb, A., McCowan, B., Capitanio, J.P.

744 (2018) 'Personality, environmental stressors, and diarrhea in rhesus macaques: an

745 interactionist perspective', American Journal of Primatology, 80(12).

746 Grampp, M., Sueur, C., van de Waal, E., Botting, J. (2019) 'Social attention biases in

747 juvenile wild vervet monkeys: implications for socialisation and social learning

748 processes', Primates: Journal of Primatology, 60(3), 261-275.

749 Herrelko, E.S., Vick, S.-J., Buchanan-Smith, H.M. (2012) 'Cognitive Research in Zoo-

750 Housed Chimpanzees: Influence of Personality and Impact on Welfare', American

751 Journal of Primatology, 74(9), 828-840.

752 Higgins, E.T. (1997) 'Beyond pleasure and pain', American Psychologist, 52(12), 12807531300.

754 Highfill, L. (2008) 'The use of personality assessments in designing environmental 755 enrichment for Garnett's bushbabies (Otolemur garnettii)', Dissertations. 1143.

756 Available: https://aquila.usm.edu/dissertations/1143/

757 Highfill, L., Hanbury, D., Kristiansen, R., Kuczaj, S., Watson, S. (2010) ‘Rating vs.

758 coding in animal personality research', Zoo Biology, 29(4), 509-516.

759 Hopper, L.M., Cronin, K.A., Ross, S.R. (2018) 'A multi-institutional assessment of a 760 short-form personality questionnaire for use with macaques', Zoo Biology, 37(5), 281761289.

762 Hopper, L.M., Price, S.A., Freeman, H.D., Lambeth, S.P., Schapiro, S.J., Kendal, R.L. 763 (2014b) 'Influence of personality, age, sex, and estrous state on chimpanzee problem764 solving success', Animal cognition, 17(4), 835-847. 
765 Hosey, G., Melfi, V., Pankhurst, S. (2013) Zoo Animals: Behaviour, Management, and 766 Welfare, 2nd edition, OUP Oxford: Oxford.

767 Inoue-Murayama, M., Yokoyama, C., Yamanashi, Y., Weiss, A. (2018) ‘Common 768 marmoset (Callithrix jacchus) personality, subjective well-being, hair cortisol level and 769 AVPR1a, OPRM1, and DAT genotypes', Scientific Reports, 8(1), 10255.

770 Itoh, K. (2002) 'Personality research with non-human primates: Theoretical formulation 771 and methods', Primates, 43(3), 249-261.

772 Iwanicki, S., Lehmann, J. (2015) 'Behavioral and trait rating assessments of personality

773 in common marmosets (Callithrix jacchus)', Journal of Comparative Psychology

774 (Washington, D.C.: 1983), 129(3), 205-217.

775 Izzo, G., Bashaw, M., Campbell, J. (2011) ‘Enrichment and Individual Differences Affect 776 Welfare Indicators in Squirrel Monkeys (Saimiri sciureus)', Journal of Comparative 777 Psychology, 125, 347-52.

778 Jin, J., Su, Y., Tao, Y., Guo, S., Yu, Z. (2013) ‘Personality as a Predictor of General

779 Health in Captive Golden Snub-Nosed Monkeys (Rhinopithecus roxellana)', American

780 Journal of Primatology, 75(6), 524-533.

781 Jones, S.E., Miller, J.D., Lynam, D.R. (2011) ‘Personality, antisocial behavior, and 782 aggression: A meta-analytic review', Journal of Criminal Justice, 39(4), 329-337.

783 Kendal, R., Hopper, L.M., Whiten, A., Brosnan, S.F., Lambeth, S.P., Schapiro, S.J.,

784 Hoppitt, W. (2015) 'Chimpanzees copy dominant and knowledgeable individuals:

785 implications for cultural diversity', Evolution and Human Behavior, 36(1), 65-72.

786 King, J.E., Figueredo, A.J. (1997) ‘The Five-Factor Model plus Dominance in

787 Chimpanzee Personality', Journal of Research in Personality, 31(2), 257-271. 
788 Kleiman, D.G., Thompson, K.V., Baer, C.K. (Eds.) (2012) Wild Mammals in Captivity:

789 Principles and Techniques for Zoo Management, 2nd edition, University of Chicago

790 Press: Chicago.

791 Konečná, M., Weiss, A., Lhota, S., Wallner, B. (2012) ‘Personality in Barbary macaques

792 (Macaca sylvanus): Temporal stability and social rank', Journal of Research in

793 Personality, 46(5), 581-590.

794 Koski, S.E. (2011) 'Social personality traits in chimpanzees: temporal stability and

795 structure of behaviourally assessed personality traits in three captive populations',

796 Behavioral Ecology and Sociobiology, 65(11), 2161-2174.

797 Koski, S.E., Buchanan-Smith, H.M., Ash, H., Bukart, J. M., Bugnyar, T., Weiss, A.

798 (2017) ‘Common marmosets (Callithrix jacchus) Personality’, Journal of Comparative

799 Psychology, 131(4), 326-336.

800 Koski, S.E., Burkart, J.M. (2015) ‘Common marmosets show social plasticity and group-

801 level similarity in personality', Scientific Reports, 5(1), 8878.

802 Kuhar, C.W., Stoinski, T.S., Lukas, K.E., Maple, T.L. (2006) ‘Gorilla Behavior Index

803 revisited: Age, housing and behavior', Applied Animal Behaviour Science, 96(3), 315-

804326.

805 Lehmann, J., Korstjens, A.H., Dunbar, R.I.M. (2007) ‘Group size, grooming and social 806 cohesion in primates', Animal Behaviour, 74(6), 1617-1629.

807 Lutz, C.K., Brown, T.A. (2018) ‘Porches as Enrichment for Singly Housed Cynomolgus

808 Macaques (Macaca fascicularis)', Journal of the American Association for Laboratory

809 Animal Science: JAALAS, 57(2), 134-137. 
810 Manson, J.H., Perry, S. (2013) 'Personality structure, sex differences, and temporal 811 change and stability in wild white-faced capuchins (Cebus capucinus).', Journal of

812 Comparative Psychology, 127(3), 299-311.

813 Martin, J.S., Suarez, S.A. (2017) 'Personality assessment and model comparison with 814 behavioral data: A statistical framework and empirical demonstration with bonobos (Pan 815 paniscus)', American Journal of Primatology, 79(8), e22670.

816 Martin-Wintle, M.S., Shepherdson, D., Zhang, G., Huang, Y., Luo, B., Swaisgood, R.R.

817 (2017) 'Do opposites attract? Effects of personality matching in breeding pairs of captive 818 giant pandas on reproductive success', Biological Conservation, 207, 27-37.

819 Masilkova, M., Weiss, A., Konečná, M. (2018) 'How long does it take? Reliable 820 personality assessment based on common behaviour in cotton-top tamarins (Saguinus 821 oedipus)', Behavioural Processes, 157, 59-67.

822 Mason, G.J. (2010) 'Species differences in responses to captivity: stress, welfare and 823 the comparative method', Trends in Ecology \& Evolution, 25(12), 713-721.

824 Massen, J.J.M., Antonides, A., Arnold, A.-M.K., Bionda, T., Koski, S.E. (2013) 'A 825 behavioral view on chimpanzee personality: Exploration tendency, persistence, 826 boldness, and tool-orientation measured with group experiments', American Journal of 827 Primatology, 75(9), 947-958.

828 Massen, J.J.M., Koski, S.E. (2014) 'Chimps of a feather sit together: chimpanzee 829 friendships are based on homophily in personality', Evolution and Human Behavior, $83035(1), 1-8$.

831 McCowan, B., Beisner, B.A., Capitanio, J.P., Jackson, M.E., Cameron, A.N., Seil, S., 832 Atwill, E.R., Fushing, H. (2011) 'Network Stability Is a Balancing Act of Personality, 
833 Power, and Conflict Dynamics in Rhesus Macaque Societies', PLoS ONE, 6(8), 834 available: https://www.ncbi.nlm.nih.gov/pmc/articles/PMC3153932/ [accessed 4 Jul 835 2020].

836 McDougall, P.T., Réale, D., Sol, D., Reader, S.M. (2006) 'Wildlife conservation and 837 animal temperament: causes and consequences of evolutionary change for captive, 838 reintroduced, and wild populations', Animal Conservation, 9(1), 39-48.

839 Melfi, V. (2005) 'The appliance of science to zoo-housed primates', Applied Animal 840 Behaviour Science, Primates in Zoos, 90(2), 97-106.

841 Melfi, V.A., Dorey, N., Ward, S.J. (2020) Zoo Animal Learning and Training, Wiley842 Blackwell: Hoboken, NJ.

843 Molesti, S., Majolo, B. (2016) 'Cooperation in wild Barbary macaques: factors affecting 844 free partner choice', Animal Cognition, 19(1), 133-146.

845 Morton, F.B., Lee, P.C., Buchanan-Smith, H.M. (2013) 'Taking personality selection bias 846 seriously in animal cognition research: a case study in capuchin monkeys (Sapajus 847 apella)', Animal Cognition, 16(4), 677-684.

848 Morton, F.B., Lee, P.C., Buchanan-Smith, H.M., Brosnan, S.F., Thierry, B., Paukner, A., 849 de Waal, F.B.M., Widness, J., Essler, J.L., Weiss, A. (2013) 'Personality Structure in 850 Brown Capuchin Monkeys: Comparisons with Chimpanzees, Orangutans, and Rhesus 851 Macaques', Journal of Comparative Psychology, 127(3), 282-298.

852 Morton, F.B., Weiss, A., Buchanan-Smith, H.M., Lee, P.C. (2015) 'Capuchin monkeys 853 with similar personalities have higher-quality relationships independent of age, sex, 854 kinship and rank', Animal Behaviour, 105, 163-171. 
855 Polgár, Z., Wood, L., Haskell, M.J. (2017) 'Individual differences in zoo-housed squirrel 856 monkeys' (Saimiri sciureus) reactions to visitors, research participation, and personality 857 ratings', American Journal of Primatology, 79(5), e22639.

858 Polit, D.F., Beck, C.T. (2010) 'Generalization in quantitative and qualitative research: 859 Myths and strategies', International Journal of Nursing Studies, 47(11), 1451-1458. 860 Powell, D., Gartner, M. (2011) 'Applications of Personality to the Management and 861 Conservation of Nonhuman Animals', 185-199.

862 Pritchard, A.J., Sheeran, L.K., Gabriel, K.I., Li, J.-H., Wagner, R.S. (2014) 'Behaviors 863 that predict personality components in adult free-ranging Tibetan macaques Macaca 864 thibetana', Current Zoology, 60(3), 362-372.

865 Račevska, E., Hill, C.M. (2017) 'Personality and social dynamics of zoo-housed western 866 lowland gorillas', Journal of Zoo and Aquarium Research, 5(3), 116-122.

867 Reamer, L.A., Haller, R.L., Thiele, E.J., Freeman, H.D., Lambeth, S.P., Schapiro, S.J. 868 (2014) 'Factors affecting initial training success of blood glucose testing in captive 869 chimpanzees (Pan troglodytes)', Zoo Biology, 33(3), 212-220.

870 Robinson, L.M., Altschul, D.M., Wallace, E.K., Úbeda, Y., Llorente, M., Machanda, Z., 871 Slocombe, K.E., Leach, M.C., Waran, N.K., Weiss, A. (2017) 'Chimpanzees with 872 positive welfare are happier, extraverted, and emotionally stable', Applied Animal 873 Behaviour Science, 191, 90-97.

874 Robinson, L.M., Coleman, K., Capitanio, J.P., Gottlieb, D.H., Handel, I.G., Adams, M.J., 875 Leach, M.C., Waran, N.K., Weiss, A. (2018) 'Rhesus macaque personality, dominance, 876 behavior, and health', American Journal of Primatology, 80(2):10.1002/ajp.22739 
877 Robinson, L.M., Waran, N.K., Leach, M.C., Morton, F.B., Paukner, A., Lonsdorf, E.,

878 Handel, I., Wilson, V.A.D., Brosnan, S.F., Weiss, A. (2016) 'Happiness is positive

879 welfare in brown capuchins (Sapajus apella)', Applied Animal Behaviour Science, 181, $880 \quad 145-151$.

881 Ruhde, A.A., Baker, K.C., Russell-Lodrigue, K.E., Blanchard, J.L., Bohm, R.P. (2020)

882 'Trio housing of adult male rhesus macaques (Macaca mulatta): Methodology and 883 outcome predictors', Journal of Medical Primatology, 49(4), 188-201..

884 Schaefer, S.A., Steklis, H.D. (2014) 'Personality and subjective well-being in captive 885 male western lowland gorillas living in bachelor groups', American Journal of 886 Primatology, 76(9), 879-889.

887 Schapiro, S.J. (Ed.) (2017) Handbook of Primate Behavioral Management, 1st edition, 888 CRC Press.

889 Seyfarth, R.M., Silk, J.B., Cheney, D.L. (2012) 'Variation in personality and fitness in 890 wild female baboons', Proceedings of the National Academy of Sciences, 109(42), $891 \quad 16980-16985$.

892 Seyfarth, R.M., Silk, J.B., Cheney, D.L. (2014) 'Social bonds in female baboons: the 893 interaction between personality, kinship and rank', Animal Behaviour, 87, 23-29.

894 Šlipogor, V., Oliveira, T.G., Tadić, Z., Massen, J.J.M., Bugnyar, T. (2016) ‘Consistent 895 inter-individual differences in common marmosets (Callithrix jacchus) in Boldness-

896 Shyness, Stress-Activity, and Exploration-Avoidance', American Journal of Primatology, 897 78(9), 961-973.

898 Stevenson-Hinde, J., Zunz, M. (1978) ‘Subjective assessment of individual rhesus 899 monkeys', Primates, 19(3), 473-482. 
900 Stoinski, T.S., Jaicks, H.F., Drayton, L.A. (2012) 'Visitor Effects on the Behavior of 901 Captive Western Lowland Gorillas: The Importance of Individual Differences in 902 Examining Welfare', Zoo Biology, 31(5), 586-599.

903 Tetley, C., O'Hara, S. (2012) 'Ratings of animal personality as a tool for improving the 904 breeding, management and welfare of zoo mammals', Animal Welfare, 21(4), 463-476.

905 Tomassetti, D., Caracciolo, S., Manciocco, A., Chiarotti, F., Vitale, A., De Filippis, B. 906 (2019) 'Personality and lateralization in common marmosets (Callithrix jacchus)',

907 Behavioural Processes, 167, 103899.

908 Úbeda, Y., Llorente, M. (2015) ‘Personality in Sanctuary-Housed Chimpanzees: A 909 Comparative Approach of Psychobiological and Penta-Factorial Human Models', 910 Evolutionary Psychology, 13(1), 147470491501300100.

911 Uher, J., Addessi, E., Visalberghi, E. (2013) ‘Contextualised behavioural measurements 912 of personality differences obtained in behavioural tests and social observations in adult 913 capuchin monkeys (Cebus apella)', Journal of Research in Personality, 47(4), 427-444.

914 Uher, J., Visalberghi, E. (2016) 'Observations versus assessments of personality: A

915 five-method multi-species study reveals numerous biases in ratings and methodological 916 limitations of standardised assessments', Journal of Research in Personality, 61, 61-79.

917 Uher, J., Werner, C.S., Gosselt, K. (2013) 'From observations of individual behaviour to 918 social representations of personality: Developmental pathways, attribution biases, and 919 limitations of questionnaire methods', Journal of Research in Personality, 47(5), 647920667. 
921 Vandeleest, J.J., McCowan, B., Capitanio, J.P. (2011) ‘Early rearing interacts with 922 temperament and housing to influence the risk for motor stereotypy in rhesus monkeys 923 (Macaca mulatta)', Applied Animal Behaviour Science, 132(1-2), 81-89.

924 Verdolin, J.L., Harper, J. (2013) 'Are shy individuals less behaviorally variable? Insights 925 from a captive population of mouse lemurs', Primates, 54(4), 309-314.

926 Verspeek, J., Staes, N., Leeuwen, E.J.C. van, Eens, M., Stevens, J.M.G. (2019) 927 'Bonobo personality predicts friendship', Scientific Reports, 9, available:

928 https://www.ncbi.nlm.nih.gov/pmc/articles/PMC6917795/ [accessed 1 Jul 2020].

929 Ward, S.J., Melfi, V. (2013) 'The implications of husbandry training on zoo animal 930 response rates', Applied Animal Behaviour Science, 147(1), 179-185.

931 Watters, J.V., Powell, D.M. (2012) 'Measuring Animal Personality for Use in Population 932 Management in Zoos: Suggested Methods and Rationale', Zoo Biology, 31(1), 1-12.

933 Weinstein, T.A.R., Capitanio, J.P. (2012) 'Longitudinal Stability of Friendships in Rhesus 934 Monkeys (Macaca mulatta): Individual- and Relationship-level Effects', Journal of 935 Comparative Psychology, 126(1), 97-108.

936 Weiss, A., Gartner, M.C., Gold, K.C., Stoinski, T.S. (2013) ‘Extraversion predicts longer 937 survival in gorillas: an 18-year longitudinal study', Proceedings of the Royal Society of 938 Biological Sciences, 280(1752), available:

939 https://www.ncbi.nlm.nih.gov/pmc/articles/PMC3574299/[accessed 4 Jul 2020].

940 Weiss, A., Staes, N., Pereboom, J.J.M., Inoue-Murayama, M., Stevens, J.M.G., Eens,

941 M. (2015) 'Personality in Bonobos', Psychological Science, 26(9), 1430-1439. 
942 Weiss, A., Wilson, M.L., Collins, D.A., Mjungu, D., Kamenya, S., Foerster, S., Pusey, 943 A.E. (2017) 'Personality in the chimpanzees of Gombe National Park', Scientific Data, 944 4(1), 170146.

945 Wergård, E.-M., Westlund, K., Spångberg, M., Fredlund, H., Forkman, B. (2016)

946 'Training success in group-housed long-tailed macaques (Macaca fascicularis) is better 947 explained by personality than by social rank', Applied Animal Behaviour Science, 177, $948 \quad 52-58$.

949 Wielebnowski, N.C. (1999) 'Behavioral differences as predictors of breeding status in 950 captive cheetahs', Zoo Biology, 18(4), 335-349.

951 Wilson, V.A.D., Inoue-Murayama, M., Weiss, A. (2018) 'A comparison of personality in 952 the common and Bolivian Squirrel Monkey (Saimiri sciureus and Saimiri boliviensis)', 953 Journal of Comparative Psychology, 132(1), 24-39.

954 van Oers, K., de Jong, G., van Noordwijk, A., Kempenaers, Drent, P. (n.d.) ‘Contribution 955 of genetics to the study of animal personalities: a review of case studies', Behaviour, 956 142(9), 1185-1206. 


\section{Figure 1}

Primate genera represented in 69 studies of primate personality published since 2010.

Some studies included assessments of multiple genera; individual genera have been counted separately.

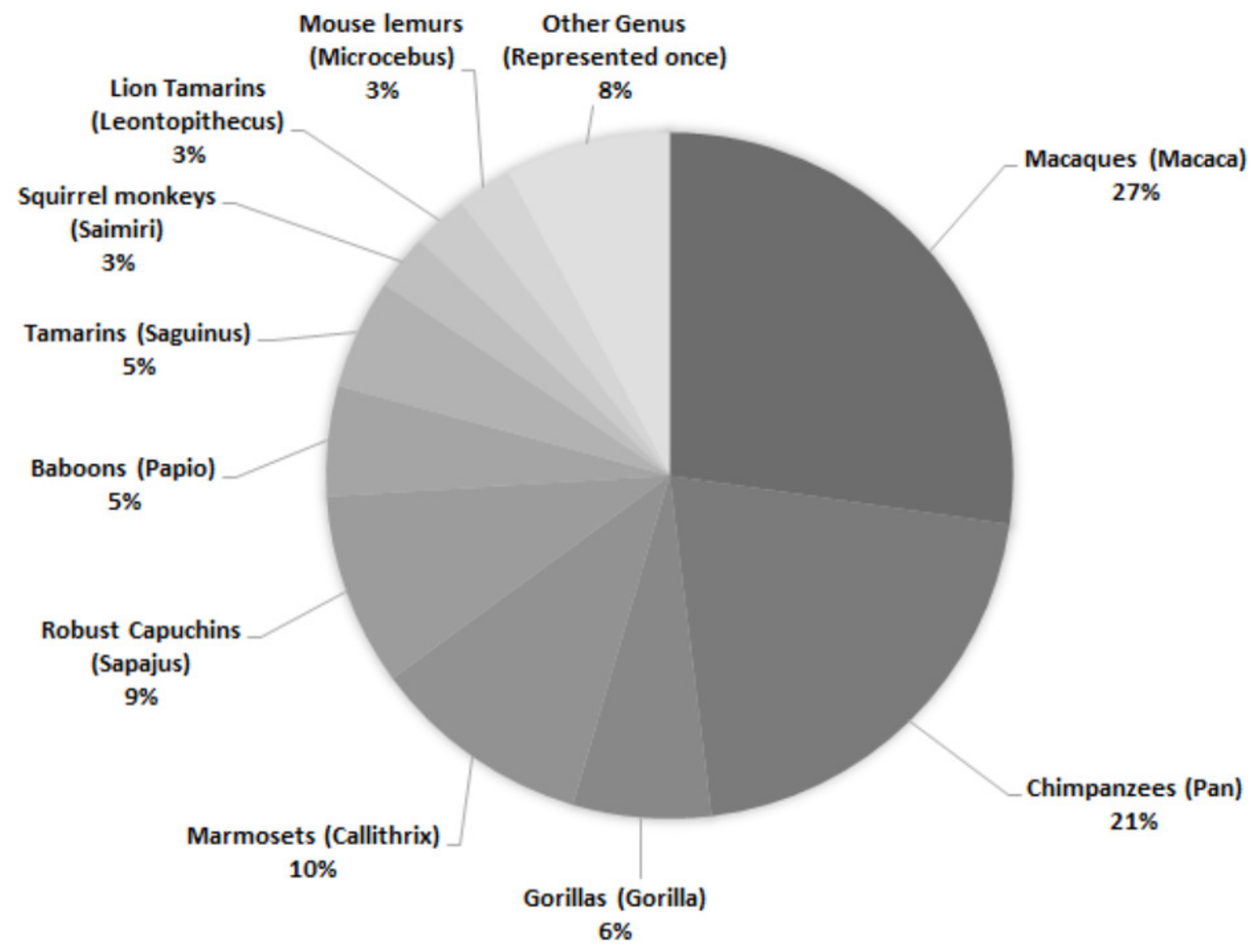




\section{Figure 2}

The five most common primate species represented across 69 studies of primate personality published since 2010 , compared against the proportion of studies carried out on other species.

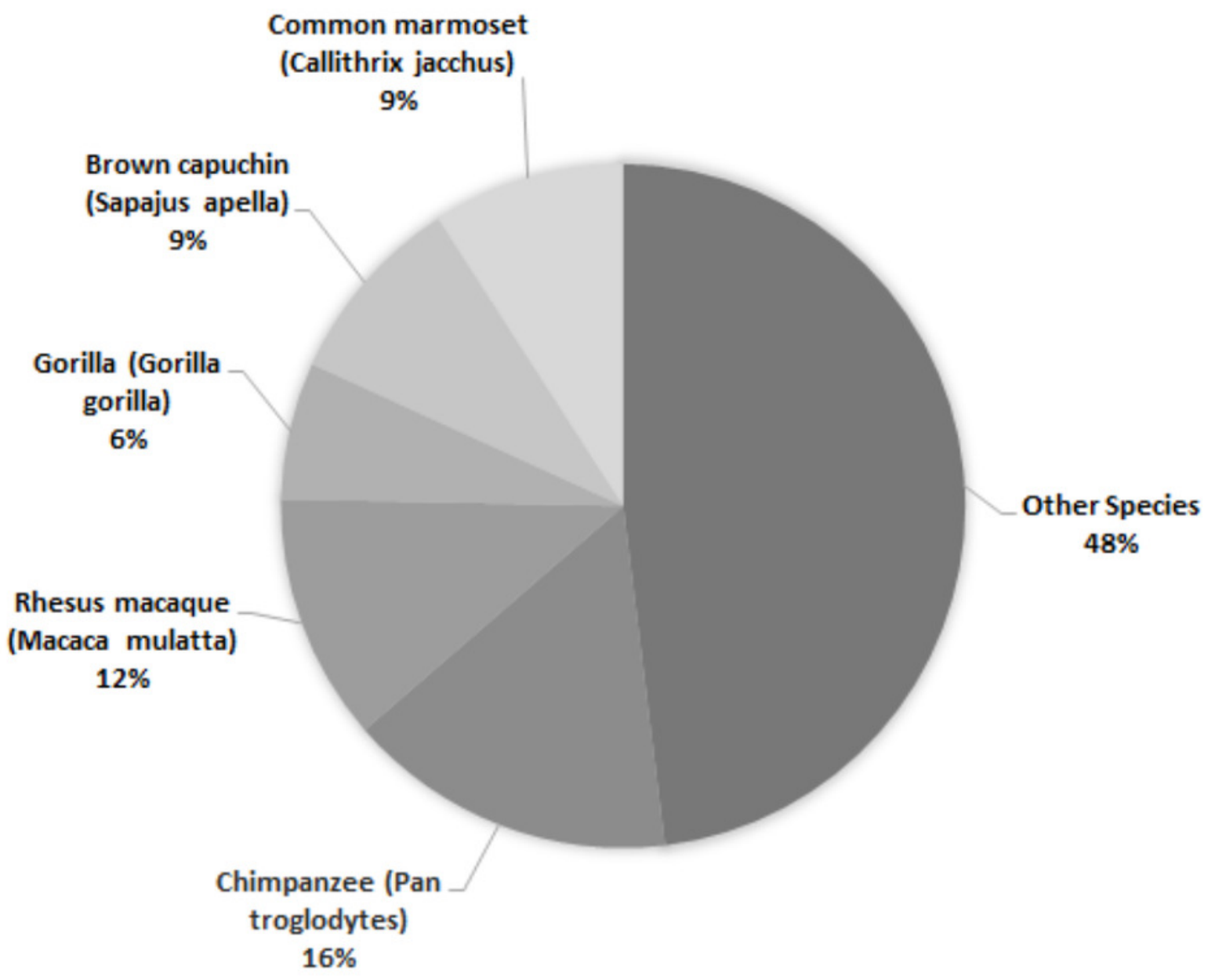




\section{Figure 3}

Primate species represented in 69 studies of primate personality conducted in zoos.

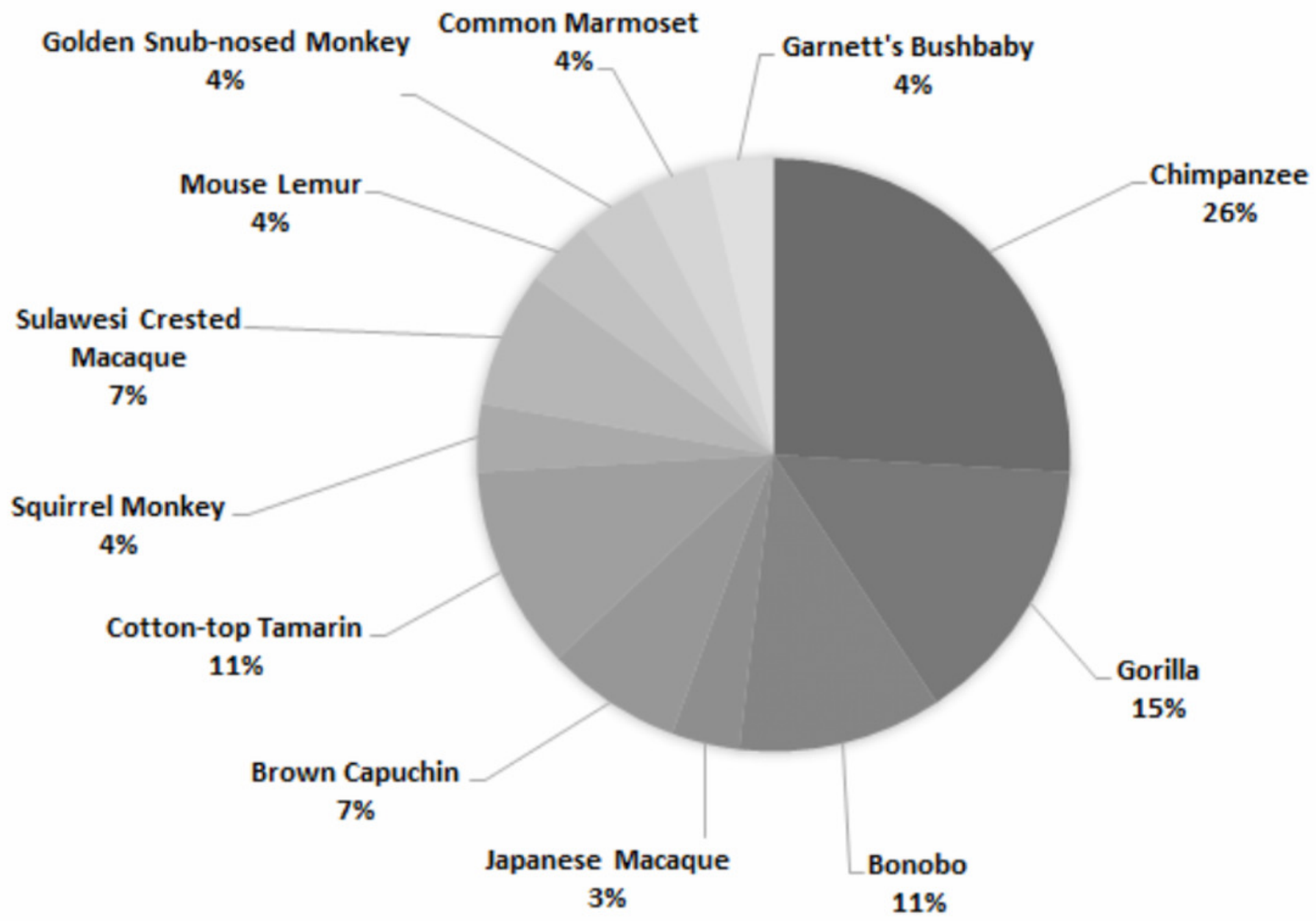




\section{Table 1 (on next page)}

Methods of personality assessment used in 69 studies of primate personality. 


\begin{tabular}{|c|c|c|c|}
\hline Method & $\begin{array}{l}\text { Proportion } \\
\text { of studies } \\
(\%)\end{array}$ & Definition & Example \\
\hline $\begin{array}{l}\text { Context } \\
\text { Tests }\end{array}$ & 39 & $\begin{array}{l}\text { Subjects partake in experimental } \\
\text { tests which are designed so that } \\
\text { animals will react differently to a } \\
\text { stimulus depending on their } \\
\text { personality. E.g. Human Intruder } \\
\text { Test, Novel Object Test }\end{array}$ & $\begin{array}{l}\text { Fernández-Lázaro et al. } \\
\text { (2019): recorded subjects' } \\
\text { behavioural responses to } \\
\text { different novel objects }\end{array}$ \\
\hline $\begin{array}{l}\text { Behavioural } \\
\text { Coding }\end{array}$ & 36 & $\begin{array}{l}\text { Observers collect behavioural data } \\
\text { of individuals within their usual } \\
\text { environment and code behaviours } \\
\text { to personality }\end{array}$ & $\begin{array}{l}\text { Martin and Suarez (2017): } \\
\text { instantaneous sampling } \\
\text { combined with event sampling } \\
\text { to produce personality models }\end{array}$ \\
\hline Trait Rating & 67 & $\begin{array}{l}\text { Observers who are familiar with } \\
\text { the subject, such as a zookeeper, } \\
\text { rates individuals against a defined } \\
\text { set of adjectives; for example, on a } \\
\text { scale that ranges from 'absence of } \\
\text { trait' to 'displays trait frequently". }\end{array}$ & $\begin{array}{l}\text { Freeman et al. (2013): } \\
\text { assessed personality of } \\
\text { chimpanzees using a 41-item } \\
\text { adjective scale }\end{array}$ \\
\hline
\end{tabular}


Table 2 (on next page)

Research focus of 69 non-human primate personality studies published after 2010. 


\begin{tabular}{|c|c|c|c|c|}
\hline Topic & $\begin{array}{c}\text { Percentage } \\
\text { (\%) }\end{array}$ & $\begin{array}{c}\text { Percentage - } \\
\text { Excluding Method } \\
\text { Validation (\%) }\end{array}$ & Definition & Example \\
\hline $\begin{array}{l}\text { Method } \\
\text { Validation }\end{array}$ & 43 & - & $\begin{array}{l}\text { Studies which aimed to validate } \\
\text { novel methods or adapt an } \\
\text { existing method to another } \\
\text { species }\end{array}$ & $\begin{array}{l}\text { Freeman } \\
\text { et al. } \\
2013\end{array}$ \\
\hline $\begin{array}{l}\text { Social } \\
\text { Behaviour }\end{array}$ & 22 & 39 & $\begin{array}{l}\text { Studies which examined } \\
\text { relationships between personality } \\
\text { and social behaviour }\end{array}$ & $\begin{array}{l}\text { Račevska } \\
\text { and Hill } \\
2017\end{array}$ \\
\hline $\begin{array}{l}\text { Animal } \\
\text { Management }\end{array}$ & 16 & 28 & $\begin{array}{l}\text { Studies which examined } \\
\text { personality in relation to daily } \\
\text { husbandry and management } \\
\text { practices e.g. enrichment, training }\end{array}$ & $\begin{array}{l}\text { Franks et } \\
\text { al. } 2013\end{array}$ \\
\hline Animal Health & 10 & 18 & $\begin{array}{l}\text { Studies which examined } \\
\text { relationships between personality } \\
\text { and physical health, e.g. } \\
\text { physiological measurements }\end{array}$ & $\begin{array}{l}\text { Costa et } \\
\text { al. } 2020\end{array}$ \\
\hline $\begin{array}{l}\text { Animal } \\
\text { Welfare }\end{array}$ & 9 & 16 & $\begin{array}{l}\text { Studies which examined } \\
\text { relationships between personality } \\
\text { and behavioural welfare } \\
\text { indicators }\end{array}$ & $\begin{array}{l}\text { Robinson } \\
\text { et al. } \\
2017\end{array}$ \\
\hline
\end{tabular}




\section{Table 3(on next page)}

Findings of personality studies on social behaviour.

Presented in order of most common species, and chronological order within species. 


\begin{tabular}{|c|c|c|c|c|}
\hline Species & Setting & Response variable(s) & $\begin{array}{l}\text { Personality Dimension(s) } \\
\text { Measured }\end{array}$ & Reference \\
\hline $\begin{array}{l}\text { Macaca } \\
\text { mulatta }\end{array}$ & $\bar{L}$ & Intervention success* & $\begin{array}{l}\text { Bold(+), Excitable(+), } \\
\text { Equable }(0) \\
\text { Bold(+), Equable }(+), \\
\text { Excitable }(0)\end{array}$ & $\begin{array}{l}\text { McCowan } \\
\text { et al. } 2011\end{array}$ \\
\hline $\begin{array}{l}\text { Macaca } \\
\text { mulatta }\end{array}$ & $\mathrm{L}$ & $\begin{array}{l}\text { Longitudinal relationship } \\
\text { stability* }^{*}\end{array}$ & $\begin{array}{l}\text { Equability }(+) \text {, Adaptability }(+), \\
\text { Confidence(0) }\end{array}$ & $\begin{array}{l}\text { Weinstein } \\
\text { and } \\
\text { Capitanio } \\
2012\end{array}$ \\
\hline $\begin{array}{l}\text { Macaca } \\
\text { mulatta }\end{array}$ & $\mathrm{L}$ & Pair success* & $\begin{array}{l}\text { Emotionality }(+) \text {, Nervous }(+) \text {, } \\
\text { Gentle(+) }\end{array}$ & $\begin{array}{l}\text { Capitanio } \\
\text { et al. } 2017\end{array}$ \\
\hline $\begin{array}{l}\text { Macaca } \\
\text { mulatta }\end{array}$ & $\mathrm{L}$ & Trio housing success & Exploratory & $\begin{array}{l}\text { Ruhde et } \\
\text { al. } 2020\end{array}$ \\
\hline $\begin{array}{l}\text { Papio } \\
\text { ursinus }\end{array}$ & W & $\begin{array}{l}\text { Bond Strength* } \\
\text { Partner Stability* } \\
\text { Glucocorticoid levels* }\end{array}$ & $\begin{array}{l}\text { Nice(+), Loner(-), Aloof(0) } \\
\text { Aloof(+), Nice(0), Loner(0) } \\
\text { Loner(+), Nice(0), Aloof(0) }\end{array}$ & $\begin{array}{l}\text { Seyfarth et } \\
\text { al. } 2012\end{array}$ \\
\hline $\begin{array}{l}\text { Papio } \\
\text { ursinus }\end{array}$ & W & $\begin{array}{l}\text { Problem solving* } \\
\text { Time spent watching } \\
\text { conspecific demonstrator } \\
\text { Improvement in problem } \\
\text { solving ability after watching } \\
\text { demonstrator* }\end{array}$ & $\begin{array}{l}\text { Bold(+), Anxious }(0) \\
\text { Bold(0), Anxious }(0)\end{array}$ & $\begin{array}{l}\text { Carter et al. } \\
2014\end{array}$ \\
\hline $\begin{array}{l}\text { Papio } \\
\text { ursinus }\end{array}$ & W & Bond strength* & $\begin{array}{l}\text { Loner(+), Aloof(+), and Nice(+) } \\
\text { homophily }\end{array}$ & $\begin{array}{l}\text { Seyfarth et } \\
\text { al. } 2014\end{array}$ \\
\hline $\begin{array}{l}\text { Macaca } \\
\text { sylvanus }\end{array}$ & W & Social rank* & $\begin{array}{l}\text { Confidence }(+) \text {, Friendliness }(0) \text {, } \\
\text { Excitability }(0)\end{array}$ & $\begin{array}{l}\text { Konečná et } \\
\text { al. } 2012\end{array}$ \\
\hline
\end{tabular}




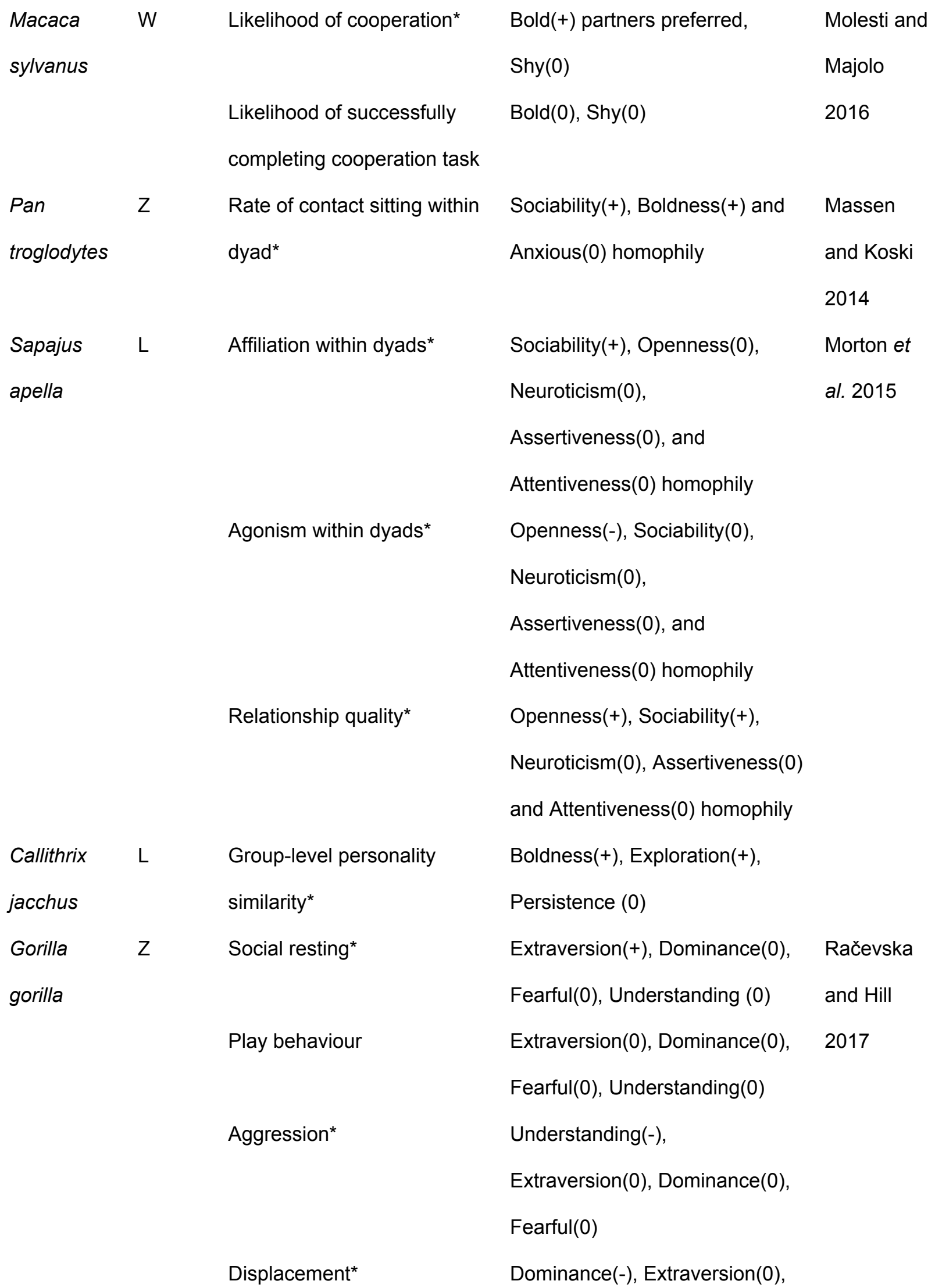




$\begin{array}{lllll} & & \text { Fearful(0), Understanding(0) } & \\ \text { Macaca } & \text { W } & \text { Bond strength* } & \text { Gregarious(+), Confidence(0), } & \text { Ebenau,et } \\ \text { assamensis } & & \text { Sociability(0), and Vigilance(0) } & \text { al. } 2019 \\ & & \text { homophily } & \\ \text { Pan } & \text { Relationship quality* } & \text { Sociability(+), Openness(0), } & \text { Verspeek } \\ \text { paniscus } & & \text { Boldness(0), and Activity(0) } & \text { et al. } 2019 \\ & & \text { homophily } & \\ & & \text { Activity }(+), \text { Sociability(0), } & \\ & & \text { Openness }(0), \text { and Boldness }(0) & \end{array}$

$1{ }^{*}$ Relationship with personality is statistically significant

$2 \quad \mathrm{Z}=\mathrm{Zoo}, \mathrm{W}=$ Wild free-living, $\mathrm{L}=$ Laboratory

$3+$ indicates significantly positive relationship, - indicates significantly negative relationship, 0 indicates no

4 significant relationship

5 


\section{Table 4(on next page)}

Findings of personality studies on animal management.

Presented in order of most common species, and chronological order within species. 


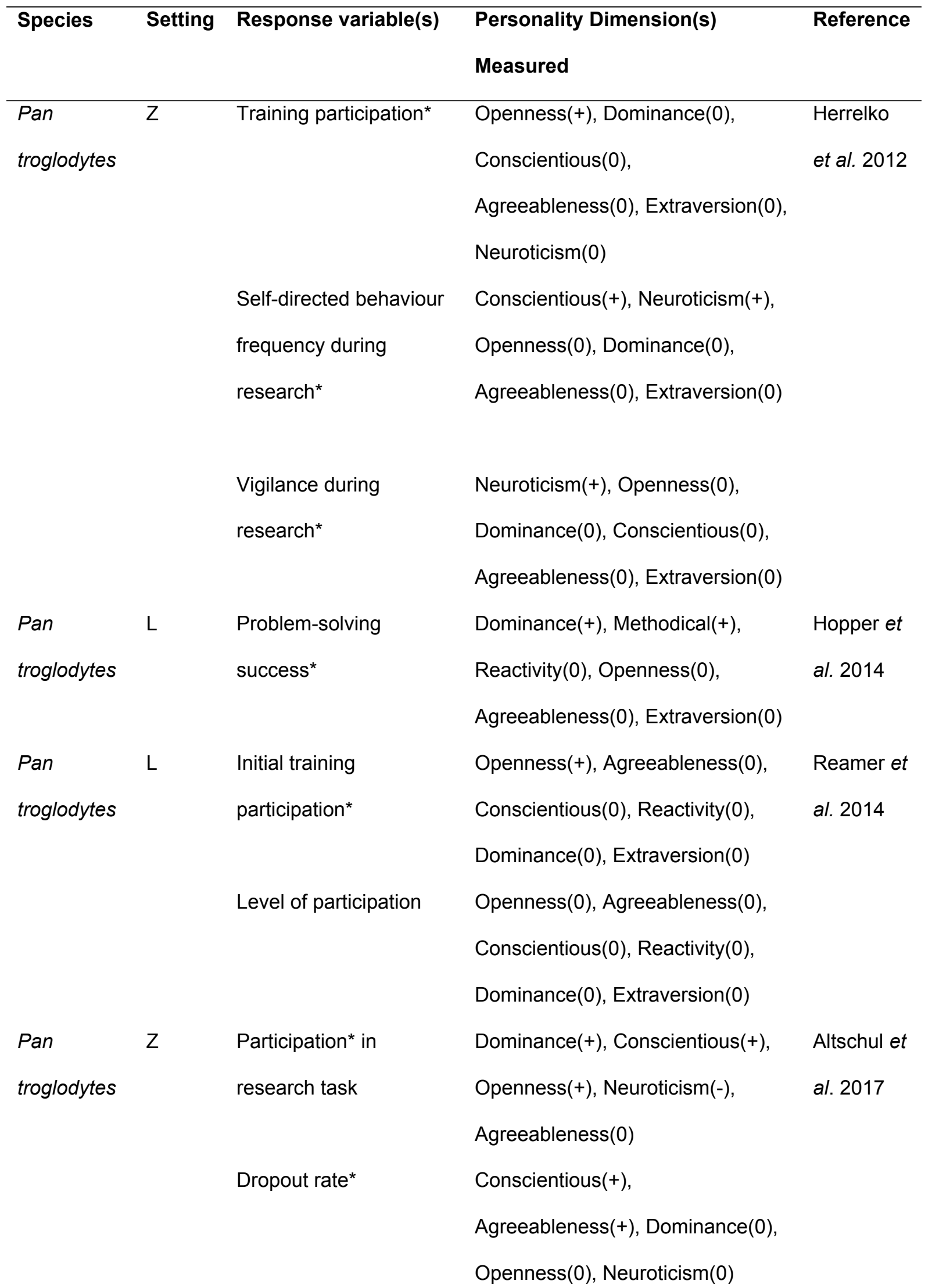




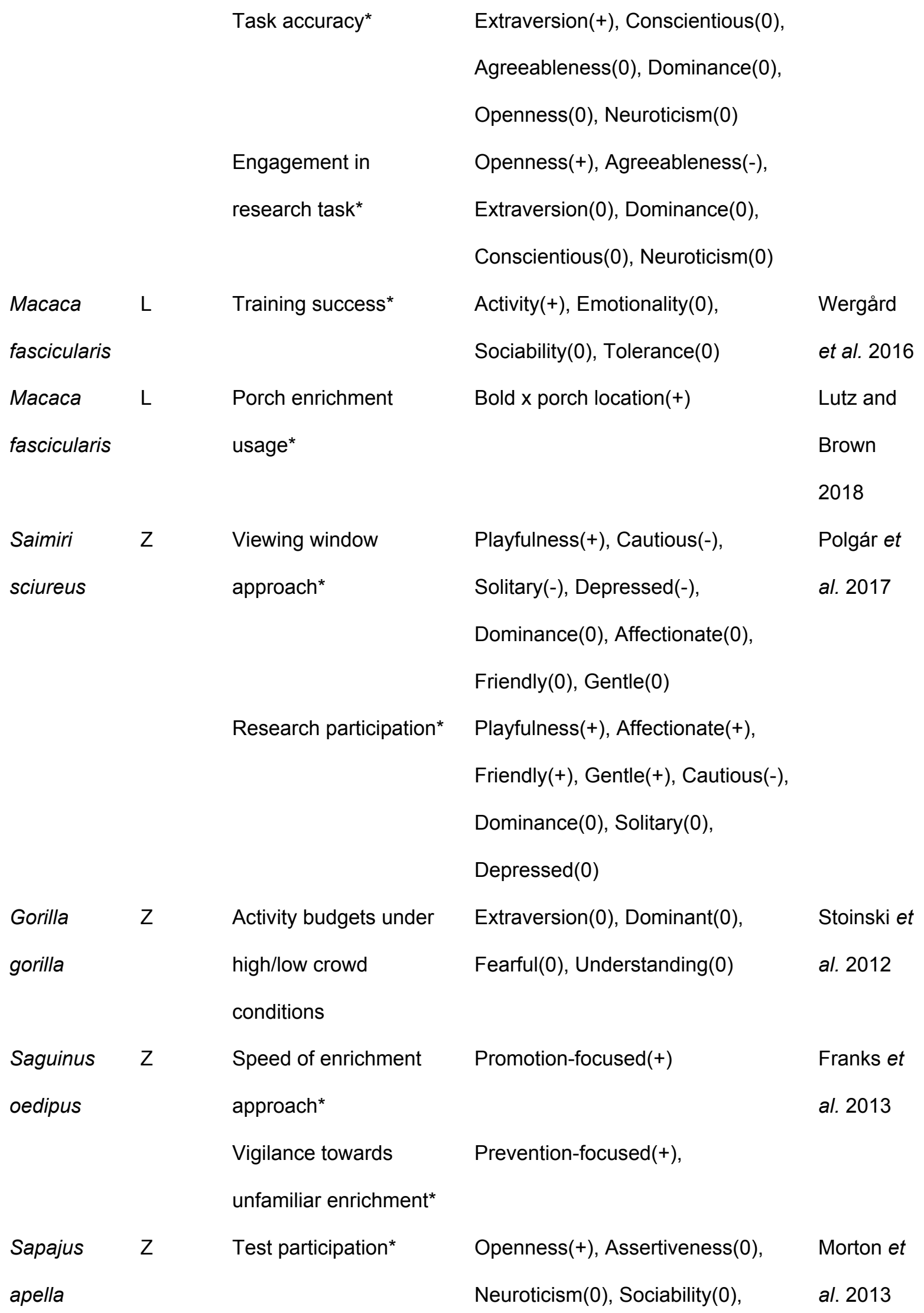




\begin{tabular}{|c|c|c|c|c|}
\hline & & & Attentiveness $(0)$ & \\
\hline & & Test performance* & Openness(+), Assertiveness(-), & \\
\hline & & & Neuroticism(0), Sociability(0), & \\
\hline & & & Attentiveness $(0)$ & \\
\hline Macaca & Z & Training cue-response & Boldness(0), Adaptability(0), & Ward and \\
\hline nigra & & latency & Fearfulness(0) & Melfi 2013 \\
\hline Macaca & $\mathrm{L}$ & Rewarded trials* & Friendliness $(+)$, Openness $(0)$ & Altschul et \\
\hline mulatta & & & $\operatorname{Anxiety}(0), \operatorname{Activity}(0)$ & al. 2016 \\
\hline & & & Dominance(0), Confidence(0) & \\
\hline & & Progress* & Friendliness $(+)$ & \\
\hline & & & Openness(+),Anxiety(0), & \\
\hline & & & Activity(0), Dominance(0), & \\
\hline & & & Confidence $(0)$ & \\
\hline & & Error* & Friendliness(-), Openness(-), & \\
\hline & & & $\operatorname{Anxiety}(0)$, Activity(0), & \\
\hline & & & Dominance(0), Confidence(0) & \\
\hline & & Reaction time & Friendliness(0), Openness $(0)$ & \\
\hline & & & $\operatorname{Anxiety}(0), \operatorname{Activity}(0)$ & \\
\hline & & & Dominance(0), Confidence(0) & \\
\hline
\end{tabular}

$1 \quad{ }^{*}$ Relationship with personality is statistically significant

$2 \quad \mathrm{Z}=\mathrm{Zoo}, \mathrm{W}=$ Wild free-living, $\mathrm{L}=$ Laboratory

3 + indicates significantly positive relationship, - indicates significantly negative relationship, 0 indicates no

4 significant relationship 


\section{Table 5 (on next page)}

Findings of personality studies on animal health.

The most common species are presented first, and chronological order within species. 


\begin{tabular}{|c|c|c|c|c|}
\hline Species & Setting & Response variable & $\begin{array}{l}\text { Personality } \\
\text { Dimension(s) Measured }\end{array}$ & Reference \\
\hline $\begin{array}{l}\text { Macaca } \\
\text { mulatta }\end{array}$ & L & Motor stereotypy risk & Gentle(0), Nervous(0) & $\begin{array}{l}\text { Vandeleest et } \\
\text { al. } 2011\end{array}$ \\
\hline $\begin{array}{l}\text { Macaca } \\
\text { mulatta }\end{array}$ & L & $\begin{array}{l}\text { Motor stereotype } \\
\text { development* }^{*}\end{array}$ & $\begin{array}{l}\text { Gentle(-), Vigilant(0), } \\
\text { Confident(0), Nervous(0) }\end{array}$ & $\begin{array}{l}\text { Gottlieb et al. } \\
2013\end{array}$ \\
\hline $\begin{array}{l}\text { Gorilla } \\
\text { gorilla }\end{array}$ & Z & Subjective well-being* & $\begin{array}{l}\text { Extraversion / } \\
\text { Agreeableness(+), } \\
\text { Dominance(+), } \\
\text { Conscientious(0) }\end{array}$ & $\begin{array}{l}\text { Schaefer and } \\
\text { Steklis } 2014\end{array}$ \\
\hline $\begin{array}{l}\text { Sapajus } \\
\text { apella }\end{array}$ & L & Subjective well-being* & $\begin{array}{l}\text { Assertiveness }(+), \\
\text { Sociability }(+) \\
\text { Openness }(0) \\
\text { Neuroticism }(0) \\
\text { Attentiveness }(0)\end{array}$ & $\begin{array}{l}\text { Robinson et al. } \\
2016\end{array}$ \\
\hline $\begin{array}{l}\text { Pan } \\
\text { troglodytes }\end{array}$ & Z & Subjective well-being* & $\begin{array}{l}\text { Openness(+), } \\
\text { Extraversion(+), } \\
\text { Neuroticism(-), } \\
\text { Dominance(0), } \\
\text { Agreeableness }(0) \\
\text { Conscientious }(0)\end{array}$ & $\begin{array}{l}\text { Robinson et al. } \\
2017\end{array}$ \\
\hline $\begin{array}{l}\text { Callithrix } \\
\text { jacchus }\end{array}$ & L & Hair cortisol levels* & $\begin{array}{l}\text { Sociability(+), } \\
\text { Neuroticism(-), } \\
\text { Dominance(0) } \\
\text { Dominance(+), } \\
\text { Sociability(+), } \\
\text { Neuroticism(0) }\end{array}$ & $\begin{array}{l}\text { Inoue- } \\
\text { Murayama et } \\
\text { al. } 2018\end{array}$ \\
\hline
\end{tabular}

$1{ }^{*}$ Relationship with personality is statistically significant 
$2 \quad \mathrm{Z}=\mathrm{Zoo}, \mathrm{W}=$ Wild free-living, $\mathrm{L}=$ Laboratory

3 + indicates significantly positive relationship, - indicates significantly negative relationship, 0 indicates no

4 significant relationship

5 
Table 6(on next page)

Findings of personality studies on animal welfare.

Presented in chronological order. 


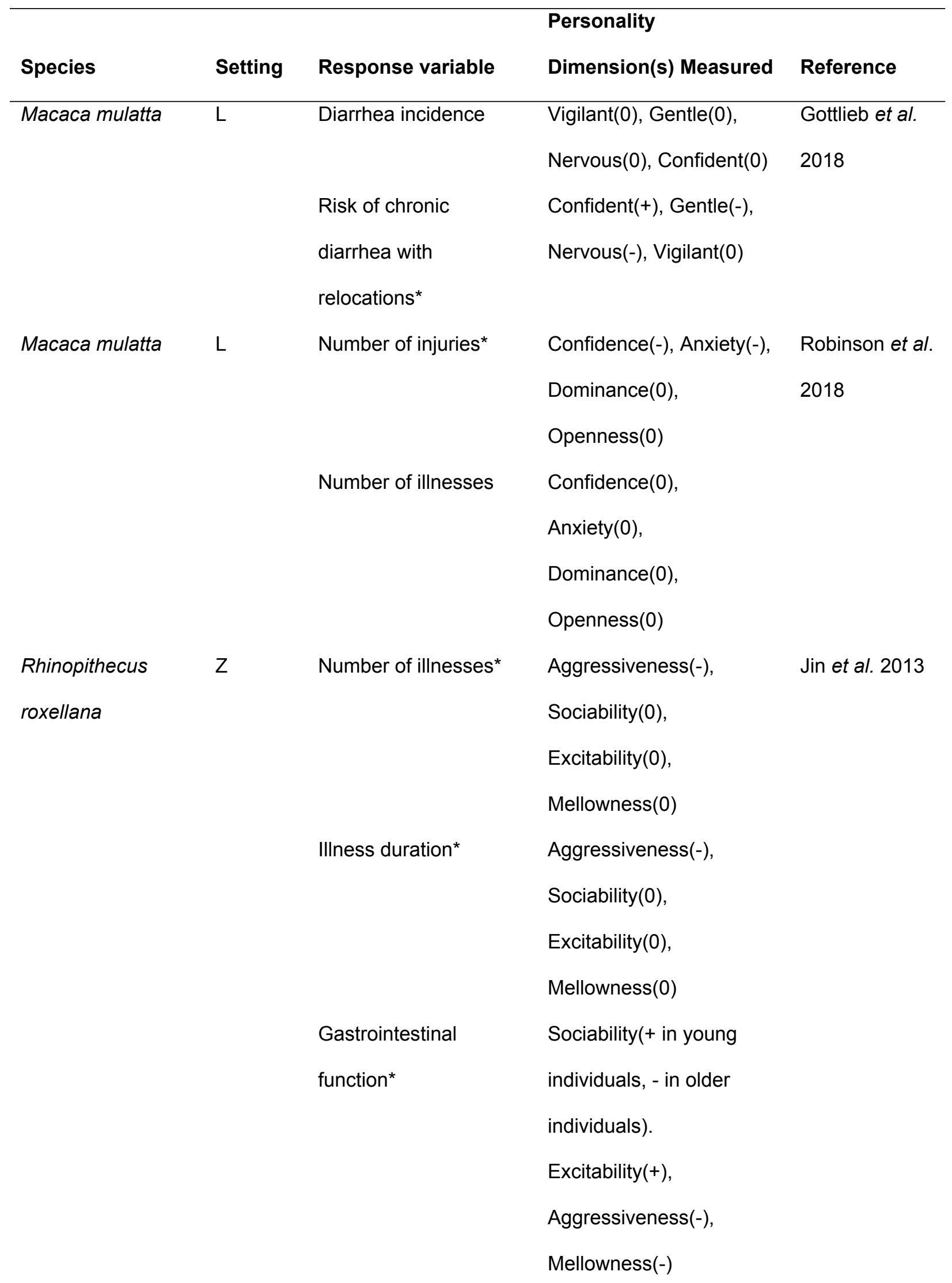




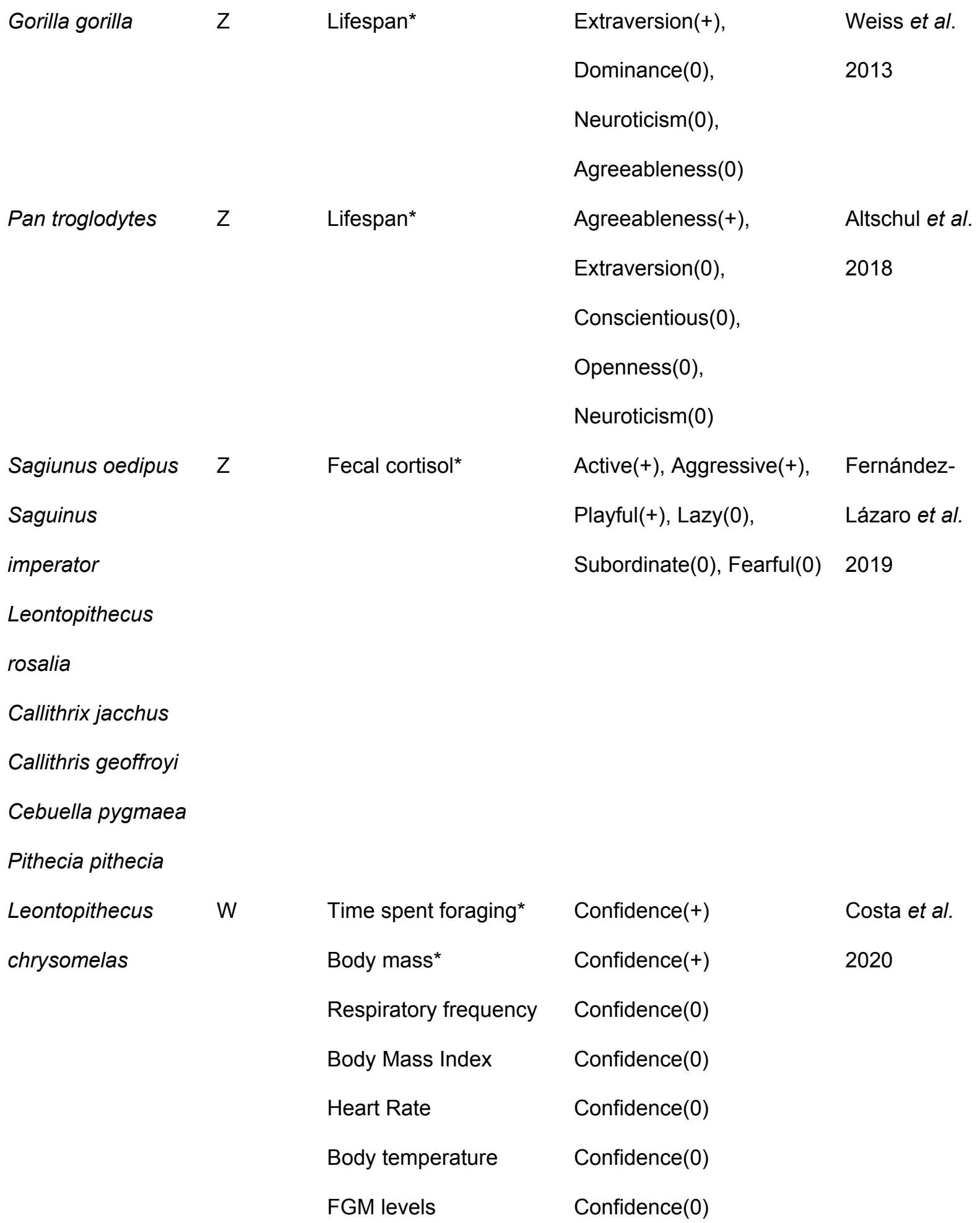

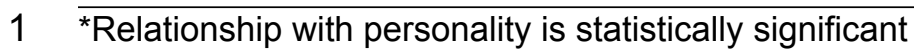

$2 \quad \mathrm{Z}=\mathrm{Zoo}, \mathrm{W}=$ Wild free-living, $\mathrm{L}=$ Laboratory 
3 + indicates significantly positive relationship, - indicates significantly negative relationship, 0 indicates no

4 significant relationship

5 


\section{Table 7 (on next page)}

Table of surveyed data for 69 published articles on primate personality which were highlighted for this review, presented in order of publication. 


\begin{tabular}{|c|c|c|c|c|}
\hline Study & Species & Context & Focus & Method \\
\hline $\begin{array}{l}\text { Highfill et } \\
\text { al. (2010) }\end{array}$ & $\begin{array}{l}\text { Garnett's Bushbaby } \\
\text { (Otolemur garnettii) }\end{array}$ & $\begin{array}{l}\text { Zoo-housed } \\
\text { animals }\end{array}$ & $\begin{array}{l}\text { Method Validation - } \\
\text { comparing rating and } \\
\text { coding as assessment } \\
\text { methods }\end{array}$ & $\begin{array}{l}\text { Trait Rating } \\
+ \\
\text { Behaviour } \\
\text { Coding }\end{array}$ \\
\hline $\begin{array}{l}\text { McCowan } \\
\text { et al. } \\
(2011)\end{array}$ & $\begin{array}{l}\text { Rhesus Macaque } \\
\text { (Macaca mulatta) }\end{array}$ & $\begin{array}{l}\text { Laboratory } \\
\text { animals }\end{array}$ & $\begin{array}{l}\text { Social Behaviour - } \\
\text { demonstrating role of } \\
\text { personality in social } \\
\text { network dynamics }\end{array}$ & $\begin{array}{l}\text { Trait Rating } \\
+ \\
\text { Behaviour } \\
\text { Coding }\end{array}$ \\
\hline $\begin{array}{l}\text { Koski } \\
(2011)\end{array}$ & $\begin{array}{l}\text { Chimpanzee } \\
\text { (Pan troglodytes) }\end{array}$ & $\begin{array}{l}\text { Zoo-housed } \\
\text { animals }\end{array}$ & $\begin{array}{l}\text { Method Validation - } \\
\text { examining predictive } \\
\text { validity of social } \\
\text { personality traits over } \\
\text { time }\end{array}$ & $\begin{array}{l}\text { Behaviour } \\
\text { Coding }\end{array}$ \\
\hline $\begin{array}{l}\text { Vandeleest } \\
\text { et al. } \\
(2011)\end{array}$ & $\begin{array}{l}\text { Rhesus Macaque } \\
\text { (Macaca mulatta) }\end{array}$ & $\begin{array}{l}\text { Laboratory } \\
\text { animals }\end{array}$ & $\begin{array}{l}\text { Animal Welfare - } \\
\text { relationship between } \\
\text { personality and motor } \\
\text { stereotypy risk }\end{array}$ & $\begin{array}{l}\text { Context } \\
\text { Tests + } \\
\text { Trait Rating }\end{array}$ \\
\hline $\begin{array}{l}\text { Carter et al. } \\
(2012)\end{array}$ & $\begin{array}{l}\text { Chacma Baboon } \\
\text { (Papio ursinus) }\end{array}$ & $\begin{array}{l}\text { Free-living } \\
\text { animals }\end{array}$ & $\begin{array}{l}\text { Method Validation - } \\
\text { testing cross-context } \\
\text { consistency of a } \\
\text { personality assessment }\end{array}$ & $\begin{array}{l}\text { Context } \\
\text { Tests }\end{array}$ \\
\hline Dammhahn & Mouse Lemur & Free-living & Method Validation - & Context \\
\hline
\end{tabular}




\begin{tabular}{|c|c|c|c|c|}
\hline and & (Microcebus & animals & testing cross-context & Tests \\
\hline $\begin{array}{l}\text { Almeling } \\
\text { (2012) }\end{array}$ & murinus) & & $\begin{array}{l}\text { consistency of a } \\
\text { personality assessment }\end{array}$ & \\
\hline $\begin{array}{l}\text { Herrelko et } \\
\text { al. (2012) }\end{array}$ & $\begin{array}{l}\text { Chimpanzee } \\
\text { (Pan troglodytes) }\end{array}$ & $\begin{array}{l}\text { Zoo-housed } \\
\text { animals }\end{array}$ & $\begin{array}{l}\text { Management - influence } \\
\text { of personality on } \\
\text { behaviour outcomes } \\
\text { during training }\end{array}$ & Trait Rating \\
\hline $\begin{array}{l}\text { Konečná et } \\
\text { al. (2012) }\end{array}$ & $\begin{array}{l}\text { Barbary Macaque } \\
\text { (Macaca sylvanus) }\end{array}$ & $\begin{array}{l}\text { Free-living } \\
\text { animals }\end{array}$ & $\begin{array}{l}\text { Social Behaviour - } \\
\text { examining relationship } \\
\text { between personality and } \\
\text { social rank }\end{array}$ & Trait Rating \\
\hline $\begin{array}{l}\text { Seyfarth et } \\
\text { al. (2012) }\end{array}$ & $\begin{array}{l}\text { Chacma Baboon } \\
\text { (Papio ursinus) }\end{array}$ & $\begin{array}{l}\text { Free-living } \\
\text { animals }\end{array}$ & $\begin{array}{l}\text { Social Behaviour - } \\
\text { examining correlations } \\
\text { between personality and } \\
\text { fitness }\end{array}$ & $\begin{array}{l}\text { Behaviour } \\
\text { Coding }\end{array}$ \\
\hline $\begin{array}{l}\text { Stoinski et } \\
\text { al. (2012) }\end{array}$ & $\begin{array}{l}\text { Gorilla } \\
\text { (Gorilla gorilla) }\end{array}$ & $\begin{array}{l}\text { Zoo-housed } \\
\text { animals }\end{array}$ & $\begin{array}{l}\text { Management - } \\
\text { comparing individual } \\
\text { differences and response } \\
\text { to visitor numbers }\end{array}$ & Trait Rating \\
\hline $\begin{array}{l}\text { Weinstein } \\
\text { and }\end{array}$ & $\begin{array}{l}\text { Rhesus Macaque } \\
\text { (Macaca mulatta) }\end{array}$ & $\begin{array}{l}\text { Laboratory } \\
\text { animals }\end{array}$ & $\begin{array}{l}\text { Social Behaviour - } \\
\text { longitudinal study of }\end{array}$ & $\begin{array}{l}\text { Context } \\
\text { Tests + }\end{array}$ \\
\hline $\begin{array}{l}\text { Capitanio } \\
(2012)\end{array}$ & & & $\begin{array}{l}\text { personality and friendship } \\
\text { stability }\end{array}$ & Trait Rating \\
\hline
\end{tabular}




\begin{tabular}{|c|c|c|c|c|}
\hline $\begin{array}{l}\text { Franks et } \\
\text { al. (2013) }\end{array}$ & $\begin{array}{l}\text { Cotton-top Tamarin } \\
\text { (Saguinus oedipus) }\end{array}$ & $\begin{array}{l}\text { Zoo-housed } \\
\text { animals }\end{array}$ & $\begin{array}{l}\text { Management - examining } \\
\text { relationship between } \\
\text { personality and } \\
\text { enrichment use }\end{array}$ & $\begin{array}{l}\text { Context } \\
\text { Tests }\end{array}$ \\
\hline $\begin{array}{l}\text { Freeman et } \\
\text { al. (2013) }\end{array}$ & $\begin{array}{l}\text { Chimpanzee } \\
\text { (Pan troglodytes) }\end{array}$ & $\begin{array}{l}\text { Laboratory } \\
\text { animals }\end{array}$ & $\begin{array}{l}\text { Method Validation - } \\
\text { assessing validity of } \\
\text { novel, comprehensive } \\
\text { assessment }\end{array}$ & $\begin{array}{l}\text { Trait Rating } \\
+ \\
\text { Behaviour } \\
\text { Coding }\end{array}$ \\
\hline $\begin{array}{l}\text { Gottlieb et } \\
\text { al. (2013) }\end{array}$ & $\begin{array}{l}\text { Rhesus Macaque } \\
\text { (Macaca mulatta) }\end{array}$ & $\begin{array}{l}\text { Laboratory } \\
\text { animals }\end{array}$ & $\begin{array}{l}\text { Animal Welfare - } \\
\text { relationship between } \\
\text { personality and } \\
\text { stereotypic behaviours }\end{array}$ & $\begin{array}{l}\text { Context } \\
\text { Tests }+ \\
\text { Trait Rating }\end{array}$ \\
\hline $\begin{array}{l}\text { Iwanicki } \\
\text { and } \\
\text { Lehmann } \\
\text { (2013) }\end{array}$ & $\begin{array}{l}\text { Common Marmoset } \\
\text { (Callithrix jacchus) }\end{array}$ & $\begin{array}{l}\text { Zoo-housed } \\
\text { animals }\end{array}$ & $\begin{array}{l}\text { Method Validation - } \\
\text { reliability and validity of } \\
\text { personality in marmosets }\end{array}$ & $\begin{array}{l}\text { Trait Rating } \\
+ \\
\text { Behaviour } \\
\text { Coding }\end{array}$ \\
\hline $\begin{array}{l}\text { Jin et al. } \\
\text { (2013) }\end{array}$ & $\begin{array}{l}\text { Golden snub-nosed } \\
\text { monkey } \\
\text { (Rhinopithecus } \\
\text { roxellana) }\end{array}$ & $\begin{array}{l}\text { Zoo-housed } \\
\text { animals }\end{array}$ & $\begin{array}{l}\text { Animal Health - } \\
\text { relationship between } \\
\text { personality and } \\
\text { gastrointestinal health }\end{array}$ & Trait Rating \\
\hline $\begin{array}{l}\text { Manson } \\
\text { and Perry }\end{array}$ & $\begin{array}{l}\text { White-faced } \\
\text { Capuchin (Cebus }\end{array}$ & $\begin{array}{l}\text { Free-living } \\
\text { animals }\end{array}$ & $\begin{array}{l}\text { Method Validation - } \\
\text { Structure, sex differences }\end{array}$ & Trait Rating \\
\hline
\end{tabular}




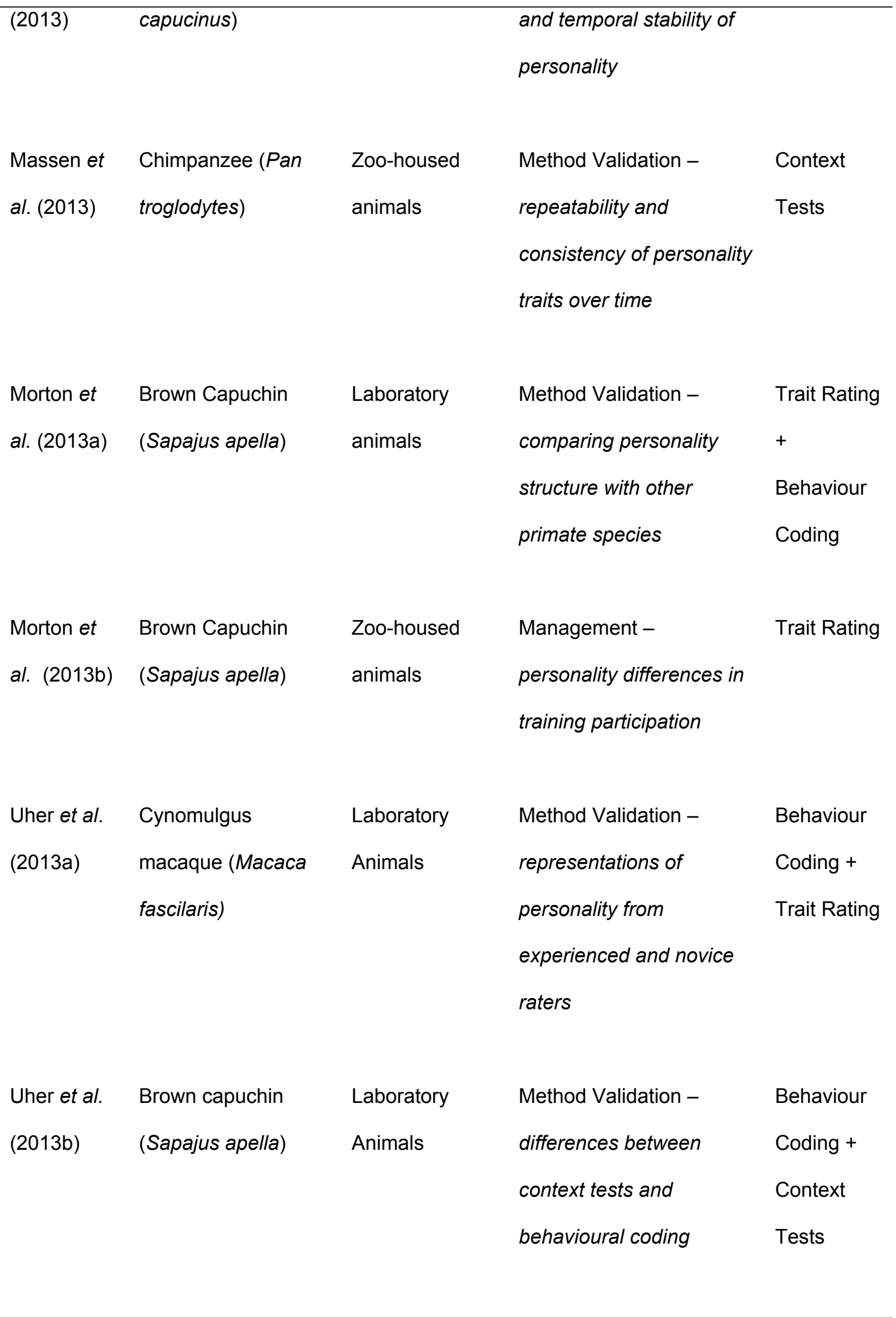




\begin{tabular}{|c|c|c|c|c|}
\hline Verdolin & Mouse Lemur & Zoo-housed & Method Validation - & Context \\
\hline $\begin{array}{l}\text { and Harper } \\
\text { (2013) }\end{array}$ & $\begin{array}{l}\text { (Microcebus } \\
\text { murinus) }\end{array}$ & animals & $\begin{array}{l}\text { demonstrating } \\
\text { consistency in personality } \\
\text { across contexts }\end{array}$ & Tests \\
\hline Ward and & Sulawesi Crested & Zoo-housed & Management - & Trait Rating \\
\hline $\begin{array}{l}\text { Melfi } \\
(2013)\end{array}$ & $\begin{array}{l}\text { Macaque } \\
\text { (Macaca nigra) }\end{array}$ & animals & $\begin{array}{l}\text { comparing personality } \\
\text { profiles with training } \\
\text { response latency }\end{array}$ & \\
\hline $\begin{array}{l}\text { Weiss et al. } \\
(2013)\end{array}$ & $\begin{array}{l}\text { Gorilla } \\
\text { (Gorilla gorilla) }\end{array}$ & $\begin{array}{l}\text { Zoo-housed } \\
\text { animals }\end{array}$ & $\begin{array}{l}\text { Animal Health - } \\
\text { examining the } \\
\text { relationship between } \\
\text { personality and lifespan }\end{array}$ & Trait Rating \\
\hline $\begin{array}{l}\text { Carter et al. } \\
(2014)\end{array}$ & $\begin{array}{l}\text { Chacma Baboon } \\
\text { (Papio ursinus) }\end{array}$ & $\begin{array}{l}\text { Free-living } \\
\text { animals }\end{array}$ & $\begin{array}{l}\text { Social Behaviour - } \\
\text { associations between } \\
\text { personality and social } \\
\text { learning }\end{array}$ & $\begin{array}{l}\text { Context } \\
\text { Tests }\end{array}$ \\
\hline $\begin{array}{l}\text { Hopper et } \\
\text { al. (2014) }\end{array}$ & $\begin{array}{l}\text { Chimpanzee } \\
\text { (Pan troglodytes) }\end{array}$ & $\begin{array}{l}\text { Laboratory } \\
\text { animals }\end{array}$ & $\begin{array}{l}\text { Management - influence } \\
\text { of internal factors on } \\
\text { problem-solving success }\end{array}$ & Trait Rating \\
\hline $\begin{array}{l}\text { Pritchard et } \\
\text { al. (2014) }\end{array}$ & $\begin{array}{l}\text { Tibetan Macaque } \\
\text { (Macaca thibetana) }\end{array}$ & $\begin{array}{l}\text { Free-living } \\
\text { animals }\end{array}$ & $\begin{array}{l}\text { Method Validation - } \\
\text { testing methodology for } \\
\text { personality assessment in } \\
\text { Tibetan macaques }\end{array}$ & $\begin{array}{l}\text { Behaviour } \\
\text { Coding + } \\
\text { Trait Rating }\end{array}$ \\
\hline
\end{tabular}




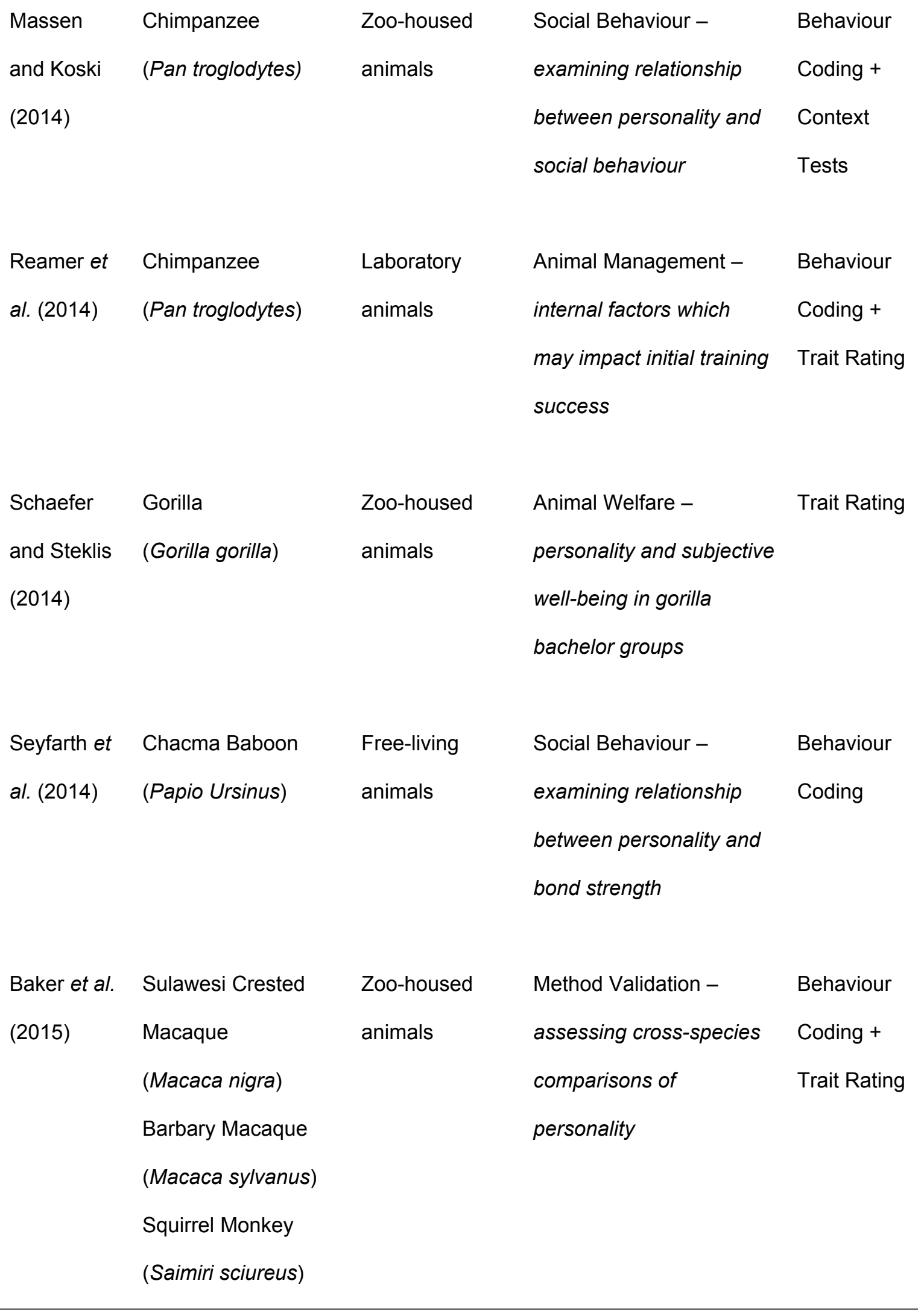




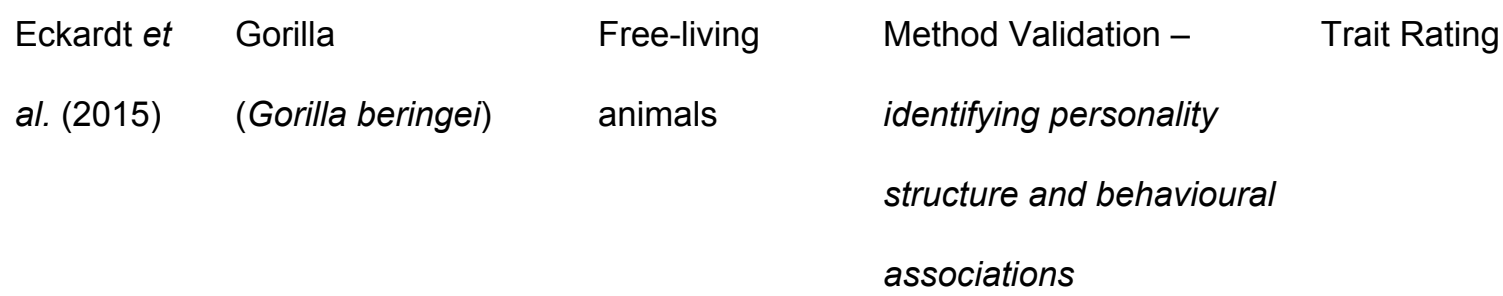

$\begin{array}{lllll}\text { Koski and } & \text { Common Marmoset } & \text { Laboratory } & \text { Social Behaviour }- & \text { Context } \\ \text { Bukart } & \text { (Callithrix jacchus) } & \text { Animals } & \text { group-level similarities in } & \text { Tests } \\ (2015) & & & \text { personality. }\end{array}$

$\begin{array}{lllll}\text { Morton et } & \text { Brown Capuchin } & \text { Laboratory } & \text { Social Behaviour }- & \text { Trait Rating } \\ \text { al. (2015) } & \text { (Sapajus apella) } & \text { animals } & \text { examining relationship } & + \\ & & & \text { between personality and } & \text { Behaviour } \\ & & & \text { bond quality } & \text { Coding } \\ \text { Úbeda and } & \text { Chimpanzee } & \text { Sanctuary } & \text { Method Validation - } & \text { Trait Rating } \\ \text { Llorente } & \text { (Pan troglodytes) } & \text { animals } & \text { validating assessment } & \\ \text { (2015) } & & & \text { method for use in } & \\ & & & \text { sanctuary chimpanzees } & \\ \text { Weiss et al. } & \text { Bonobo (Pan } & \text { Zoo-housed } & \text { Method Validation - } & \text { Trait Rating } \\ \text { (2015) } & \text { paniscus) } & \text { animals } & \text { comparisons of human } & \\ & & & \text { and bonobo personality } & \end{array}$

$\begin{array}{lllll}\text { Altschul et } & \text { Rhesus macaque } & \text { Laboratory } & \text { Management }- & \text { Trait Rating } \\ \text { al. (2016) } & \text { (Macaca mulatta) } & \text { animals } & \text { associations between } & \\ & & & \text { personality and }\end{array}$


intelligence

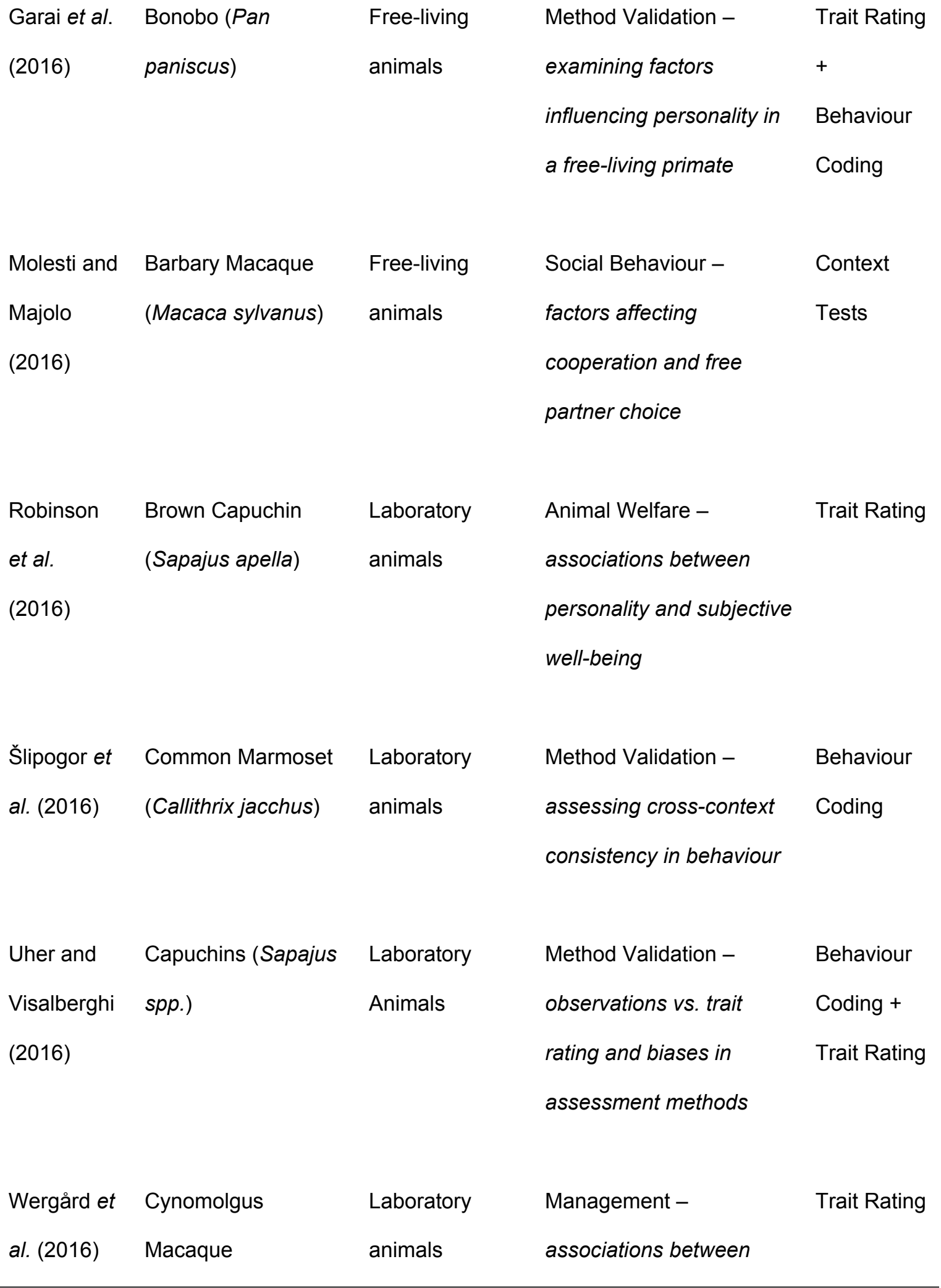




\begin{tabular}{|c|c|c|c|c|}
\hline & (Macaca fascilaris) & & $\begin{array}{l}\text { personality and training } \\
\text { success }\end{array}$ & \\
\hline $\begin{array}{l}\text { Altschul et } \\
\text { al. (2017) }\end{array}$ & $\begin{array}{l}\text { Chimpanzee (Pan } \\
\text { troglodytes) }\end{array}$ & $\begin{array}{l}\text { Zoo-housed } \\
\text { animals }\end{array}$ & $\begin{array}{l}\text { Management - } \\
\text { performance and } \\
\text { participation in a novel } \\
\text { task }\end{array}$ & Trait Rating \\
\hline $\begin{array}{l}\text { Blaszczyk } \\
\text { (2017) }\end{array}$ & $\begin{array}{l}\text { Vervet Monkey } \\
\text { (Chlorocebus } \\
\text { pygerythrus) }\end{array}$ & $\begin{array}{l}\text { Free-living } \\
\text { animals }\end{array}$ & $\begin{array}{l}\text { Method Validation - } \\
\text { assessment of method } \\
\text { validity in predicting } \\
\text { personality }\end{array}$ & $\begin{array}{l}\text { Context } \\
\text { Tests }\end{array}$ \\
\hline $\begin{array}{l}\text { Capitanio } \\
\text { et al. } \\
(2017)\end{array}$ & $\begin{array}{l}\text { Rhesus Macaque } \\
\text { (Macaca mulatta) }\end{array}$ & $\begin{array}{l}\text { Laboratory } \\
\text { animals }\end{array}$ & $\begin{array}{l}\text { Social Behaviour - } \\
\text { longitudinal impact of } \\
\text { personality on social } \\
\text { pairing success }\end{array}$ & $\begin{array}{l}\text { Context } \\
\text { Tests + } \\
\text { Trait Rating }\end{array}$ \\
\hline $\begin{array}{l}\text { Koski et al. } \\
(2017)\end{array}$ & $\begin{array}{l}\text { Common Marmoset } \\
\text { (Callithrix jacchus) }\end{array}$ & $\begin{array}{l}\text { Laboratory } \\
\text { animals }\end{array}$ & $\begin{array}{l}\text { Method Validation - } \\
\text { Identifying major } \\
\text { personality dimensions } \\
\text { and possible } \\
\text { demographic differences }\end{array}$ & Trait Rating \\
\hline $\begin{array}{l}\text { Martin and } \\
\text { Suarez } \\
(2017)\end{array}$ & $\begin{array}{l}\text { Bonobo } \\
\text { (Pan paniscus) }\end{array}$ & $\begin{array}{l}\text { Zoo-housed } \\
\text { animals }\end{array}$ & $\begin{array}{l}\text { Method Validation - } \\
\text { demonstration of novel } \\
\text { personality assessment } \\
\text { method }\end{array}$ & $\begin{array}{l}\text { Behaviour } \\
\text { Coding }\end{array}$ \\
\hline
\end{tabular}




\begin{tabular}{|c|c|c|c|c|}
\hline $\begin{array}{l}\text { Polgár et } \\
\text { al. (2017) }\end{array}$ & $\begin{array}{l}\text { Squirrel Monkey } \\
\text { (Saimiri sciureus) }\end{array}$ & $\begin{array}{l}\text { Zoo-housed } \\
\text { animals }\end{array}$ & $\begin{array}{l}\text { Management - individual } \\
\text { differences in response to } \\
\text { visitors and research } \\
\text { participation }\end{array}$ & Trait Rating \\
\hline $\begin{array}{l}\text { Račevska } \\
\text { and Hill } \\
(2017)\end{array}$ & $\begin{array}{l}\text { Gorilla } \\
\text { (Gorilla gorilla) }\end{array}$ & $\begin{array}{l}\text { Zoo-housed } \\
\text { animals }\end{array}$ & $\begin{array}{l}\text { Social Behaviour - } \\
\text { examining social } \\
\text { behaviour and personality } \\
\text { traits }\end{array}$ & Trait Rating \\
\hline $\begin{array}{l}\text { Robinson } \\
\text { et al. } \\
\text { (2017) }\end{array}$ & $\begin{array}{l}\text { Chimpanzee } \\
\text { (Pan troglodytes) }\end{array}$ & $\begin{array}{l}\text { Zoo-housed } \\
\text { animals }\end{array}$ & $\begin{array}{l}\text { Animal Welfare - } \\
\text { associations between } \\
\text { personality and subjective } \\
\text { well-being }\end{array}$ & Trait Rating \\
\hline $\begin{array}{l}\text { Weiss et al. } \\
(2017)\end{array}$ & $\begin{array}{l}\text { Chimpanzee } \\
\text { (Pan troglodytes) }\end{array}$ & $\begin{array}{l}\text { Free-living } \\
\text { animals }\end{array}$ & $\begin{array}{l}\text { Method Validation - } \\
\text { comparing temporal } \\
\text { reliability of historic and } \\
\text { modern ratings }\end{array}$ & Trait Rating \\
\hline $\begin{array}{l}\text { Altschul et } \\
\text { al. (2018) }\end{array}$ & $\begin{array}{l}\text { Chimpanzee } \\
\text { (Pan troglodytes) }\end{array}$ & $\begin{array}{l}\text { Zoo-housed } \\
\text { animals }\end{array}$ & $\begin{array}{l}\text { Animal Health - links } \\
\text { between personality and } \\
\text { longevity of chimpanzees }\end{array}$ & Trait Rating \\
\hline $\begin{array}{l}\text { Gottlieb et } \\
\text { al. (2018) }\end{array}$ & $\begin{array}{l}\text { Rhesus Macaque } \\
\text { (Macaca mulatta) }\end{array}$ & $\begin{array}{l}\text { Laboratory } \\
\text { animals }\end{array}$ & $\begin{array}{l}\text { Animal Health - } \\
\text { relationship between } \\
\text { personality, stressors and }\end{array}$ & $\begin{array}{l}\text { Context } \\
\text { Tests }+ \\
\text { Trait Rating }\end{array}$ \\
\hline
\end{tabular}




\begin{tabular}{|c|c|c|c|c|}
\hline Inoue- & Common Marmoset & Laboratory & Animal Welfare - & Trait Rating \\
\hline $\begin{array}{l}\text { Murayama } \\
\text { et al. }\end{array}$ & (Callithrix jacchus) & animals & $\begin{array}{l}\text { relationship between } \\
\text { personality subjective }\end{array}$ & \\
\hline (2018) & & & well-being & \\
\hline $\begin{array}{l}\text { Hopper et } \\
\text { al. (2018) }\end{array}$ & $\begin{array}{l}\text { Japanese Macaque } \\
\text { (Macaca fuscata) }\end{array}$ & $\begin{array}{l}\text { Zoo-housed } \\
\text { animals }\end{array}$ & $\begin{array}{l}\text { Method Validation - } \\
\text { assessing reliability of } \\
\text { short-form trait rating } \\
\text { assessment }\end{array}$ & $\begin{array}{l}\text { Trait Rating } \\
+ \text { Context } \\
\text { Tests }\end{array}$ \\
\hline Lutz and & Cynomolgus & Laboratory & Management - & Context \\
\hline $\begin{array}{l}\text { Brown } \\
(2018)\end{array}$ & $\begin{array}{l}\text { Macaque } \\
\text { (Macaca fascilaris) }\end{array}$ & animals & $\begin{array}{l}\text { personality differences in } \\
\text { enrichment (porch) usage }\end{array}$ & Tests \\
\hline $\begin{array}{l}\text { Masilkova } \\
\text { et al. } \\
(2018)\end{array}$ & $\begin{array}{l}\text { Cotton-top Tamarin } \\
\text { (Saguinus oedipus) }\end{array}$ & $\begin{array}{l}\text { Zoo-housed } \\
\text { animals }\end{array}$ & $\begin{array}{l}\text { Method Validation - } \\
\text { developing reliable and } \\
\text { efficient personality } \\
\text { assessment for tamarins }\end{array}$ & $\begin{array}{l}\text { Behaviour } \\
\text { Coding }\end{array}$ \\
\hline $\begin{array}{l}\text { Robinson } \\
\text { et al. } \\
(2018)\end{array}$ & $\begin{array}{l}\text { Rhesus Macaque } \\
\text { (Macaca mulatta) }\end{array}$ & $\begin{array}{l}\text { Laboratory } \\
\text { animals }\end{array}$ & $\begin{array}{l}\text { Animal Health - } \\
\text { associations between } \\
\text { personality, dominance, } \\
\text { and health }\end{array}$ & Trait Rating \\
\hline $\begin{array}{l}\text { Brandão et } \\
\text { al. (2019) }\end{array}$ & $\begin{array}{l}\text { Brown Capuchin } \\
\text { (Sapajus apella) }\end{array}$ & $\begin{array}{l}\text { Zoo-housed } \\
\text { animals }\end{array}$ & $\begin{array}{l}\text { Method Validation - } \\
\text { using behavioural }\end{array}$ & $\begin{array}{l}\text { Behaviour } \\
\text { Coding }\end{array}$ \\
\hline
\end{tabular}




\begin{tabular}{|c|c|c|c|c|}
\hline & & & $\begin{array}{l}\text { observations in } \\
\text { assessments of } \\
\text { capuchins }\end{array}$ & \\
\hline $\begin{array}{l}\text { Ebenau et } \\
\text { al. (2019a) }\end{array}$ & $\begin{array}{l}\text { Assamese Macaque } \\
\text { (Macaca } \\
\text { assamensis) }\end{array}$ & $\begin{array}{l}\text { Free-living } \\
\text { animals }\end{array}$ & $\begin{array}{l}\text { Method Validation - } \\
\text { providing baseline for } M \text {. } \\
\text { assamensis personality } \\
\text { research }\end{array}$ & $\begin{array}{l}\text { Behaviour } \\
\text { Coding }\end{array}$ \\
\hline $\begin{array}{l}\text { Ebenau et } \\
\text { al. (2019b) }\end{array}$ & $\begin{array}{l}\text { Assamese Macaque } \\
\text { (Macaca } \\
\text { assemensis) }\end{array}$ & $\begin{array}{l}\text { Free-living } \\
\text { animals }\end{array}$ & $\begin{array}{l}\text { Social Behaviour - } \\
\text { relationship between } \\
\text { personality and social } \\
\text { bonding in males }\end{array}$ & $\begin{array}{l}\text { Behaviour } \\
\text { Coding }\end{array}$ \\
\hline $\begin{array}{l}\text { Fernández- } \\
\text { Lázaro et } \\
\text { al. (2019) }\end{array}$ & $\begin{array}{l}\text { Cotton-top Tamarin } \\
\text { (Sagiunus oedipus) } \\
\text { Emperor Tamarin } \\
\text { (Saguinus imperator) } \\
\text { Golden lion Tamarin } \\
\text { (Leontopithecus } \\
\text { rosalia) } \\
\text { Common Marmoset } \\
\text { (Callithrix jacchus) } \\
\text { Geoffrey's Marmoset } \\
\text { (Callithris geoffroyi) } \\
\text { Pygmy Marmoset } \\
\text { (Cebuella pygmaea) } \\
\text { White-faced Saki }\end{array}$ & $\begin{array}{l}\text { Zoo-housed } \\
\text { animals }\end{array}$ & $\begin{array}{l}\text { Animal Health - cross- } \\
\text { species examination of } \\
\text { the relationship between } \\
\text { personality, lateralisation } \\
\text { and physiological welfare } \\
\text { indicators }\end{array}$ & $\begin{array}{l}\text { Context } \\
\text { Tests }+ \\
\text { Trait Rating }\end{array}$ \\
\hline
\end{tabular}


(Pithecia pithecia)

Pygmy Loris

(Nycticebus

pygmaea)

\begin{tabular}{|c|c|c|c|c|}
\hline Tomassetti & Common marmoset & Laboratory & Method Validation - & Behaviour \\
\hline $\begin{array}{l}\text { et al. } \\
(2019)\end{array}$ & (Callithrix jacchus) & Animals & $\begin{array}{l}\text { verifying presence of } \\
\text { personality and } \\
\text { comparisons with } \\
\text { lateralisation. }\end{array}$ & Coding \\
\hline $\begin{array}{l}\text { Verspeek } \\
\text { et al. } \\
(2019)\end{array}$ & $\begin{array}{l}\text { Bonobo } \\
\text { (Pan paniscus) }\end{array}$ & $\begin{array}{l}\text { Zoo-housed } \\
\text { animals }\end{array}$ & $\begin{array}{l}\text { Social Behaviour - } \\
\text { relationship between } \\
\text { personality and } \\
\text { relationship quality }\end{array}$ & $\begin{array}{l}\text { Behaviour } \\
\text { Coding }\end{array}$ \\
\hline $\begin{array}{l}\text { Costa et al. } \\
(2020)\end{array}$ & $\begin{array}{l}\text { Golden-headed lion } \\
\text { tamarin } \\
\text { (Leontopithecus } \\
\text { chrysomelas) }\end{array}$ & $\begin{array}{l}\text { Free-living } \\
\text { animals }\end{array}$ & $\begin{array}{l}\text { Animal Health - } \\
\text { examining links between } \\
\text { personality, habitat use } \\
\text { and health status }\end{array}$ & $\begin{array}{l}\text { Context } \\
\text { Tests }\end{array}$ \\
\hline $\begin{array}{l}\text { Ruhde et } \\
\text { al. (2020) }\end{array}$ & $\begin{array}{l}\text { Rhesus Macaque } \\
\text { (Macaca mulatta) }\end{array}$ & $\begin{array}{l}\text { Laboratory } \\
\text { animals }\end{array}$ & $\begin{array}{l}\text { Social Behaviour - } \\
\text { outcome predictors for } \\
\text { new social groups }\end{array}$ & $\begin{array}{l}\text { Context } \\
\text { Tests }\end{array}$ \\
\hline
\end{tabular}




\section{Table 8(on next page)}

Trait rating instruments used in reviewed non-human primate personality research, with the most commonly used tools presented first. 


\begin{tabular}{lll}
\hline Name of Trait Rating Instrument & $\begin{array}{l}\text { Proportion of } \\
\text { Trait Rating }\end{array}$ & Reference \\
& studies (\%) & \\
& 41 & (Weiss 2009; 2017) \\
\hline Hominoid Personality Questionnaire (HPQ) & 13 & (Stevenson-Hinde and Zunz 1978) \\
Maddingley Questionnaire & 11 & (Capitanio et al. 2005) \\
Biobehavioural Assessment (BBA) & & \\
Temperament Scale & 7 & (Freeman et al. 2013) \\
Freeman Questionnaire & 7 & (Fernández-Lázaro et al. 2019) \\
Undefined Trait Rating Assessment & 7 & (Kuhar et al. 2006) \\
Gorilla Behavioural Index & 2 & (Robinson et al. 2017) \\
Five Factor Model & 2 & (Ward and Melfi 2013) \\
BIAZA Behavioural Profiling Guidelines & 2 & (Uher and Visalberghi 2016) \\
Capuchin Personality Inventory & 2 & (Uher et al. 2013) \\
Macaque Personality Inventory & & \\
\hline
\end{tabular}




\section{Table 9 (on next page)}

Benefits and drawbacks of the principal personality assessment methods utilised in studies of non-human primates, synthesised across all studies. 


\begin{tabular}{|c|c|c|}
\hline Method & Benefits & Drawbacks \\
\hline Behavioural Coding & $\begin{array}{l}\text { - Produces data which is } \\
\text { comparable between subjects } \\
\text { - Measurements are objective } \\
\text { - Does not require experience with } \\
\text { individual animals }\end{array}$ & $\begin{array}{l}\text { - Time-consuming; can take hours } \\
\text { to assess each individual } \\
\text { - May not account for variability } \\
\text { due to confounding variables } \\
\text { - Based on observable behaviours } \\
\text { in one context }\end{array}$ \\
\hline Context Tests & $\begin{array}{l}\text { - High level of control limits the } \\
\text { impact of confounders } \\
\text { - Easy to conduct; the test can be } \\
\text { standardised across institutions }\end{array}$ & $\begin{array}{l}\text { - Only measures a small selection } \\
\text { of traits (e.g. fearfulness, reactivity) } \\
\text { - Not always clear how responses } \\
\text { should be measured and } \\
\text { interpreted } \\
\text { - Based on a few specific } \\
\text { behaviours }\end{array}$ \\
\hline Trait Rating & $\begin{array}{l}\text { - Quick, straightforward to complete } \\
\text { - Accounts for variability in } \\
\text { behaviour across contexts }\end{array}$ & $\begin{array}{l}\text { - Differences in familiarity with } \\
\text { subjects } \\
\text { - Measurements depend on } \\
\text { subjective judgement } \\
\text { - Requires validation to confirm } \\
\text { surveyed traits correlate with } \\
\text { observable behaviours }\end{array}$ \\
\hline
\end{tabular}

